\title{
POSSIBLE TERATOGENIC EFFECTS OF ANTIEPILEPTICS IN ALBINO RATS: COMPARATIVE STUDY BETWEEN OLD AND NEW GENERATIONS: PART II
}

\author{
Afaf M. Farghaly*, Hala M. Fathy*, Hoda A. Abd El Aziz**, Saly Y. Abd El \\ Hameed*, Huda A. Omar\# \\ *Department of forensic medicine and toxicology, faculty of medicine, Assiut \\ University, Egypt. ** Department of anatomy, faculty of medicine, Assiut University, \\ Egypt. \# Department of forensic medicine and toxicology, faculty of medicine, Aden \\ University, Yemen
}

\begin{abstract}
:
All antiepileptic drugs (AEDs) are either known or suspected of being teratogenic. The possible teratogenic mechanism is likely to be multiple even for the same drug. Treatment of females with epilepsy in the childbearing period raises questions due to interactions between epilepsy, antiepileptic drugs (AEDs) and different forms of reproductive life. The use of AEDs in these females is a balance between seizure control and adverse effects of these drugs, which are both potentially harmful to the developing fetus, neurological development, growth and subsequent pediatric progress, which presents unique challenges to both the clinicians and their patients. Recently, number of commercially available AEDs has steadily increased. This work is a randomized single blind control trial that aims to study the possible teratogenic effects of AEDs by comparing carbamazepine (old generation) with lamotrigine (new generation) in order to detect the drug that can be used safely by epileptic pregnant females. Pregnant female albino rats (120 in number) were used. They were randomly classified into six groups ( 2 control and 4 treated groups) each contained 20 pregnant rats. Animals were killed on the $20^{\text {th }}$ day of gestation, dissected and fetuses were exposed and randomly classified into two subgroups: The first (1/3 of fetuses) were eviscerated and preserved in 95\% ethyl alcohol for skeletal staining, using Alizarin red stain. Examination included: bones of axial skeleton (skull, vertebral column, sternum and ribs) and appendicular skeleton (clavicle, scapula, forelimbs and hind limbs). The second (2/3) were fixed in Bouin's solution for visceral examination.

Examination of the axial skeleton: craniofacial bones showed highly significant reduction in complete ossification centers (OCs) of all treated groups in comparison with the control with no significant difference between lamotrigine and carbamazepine in therapeutic doses. Other parts of axial skeleton were not affected in therapeutic treated groups. Appendicular skeleton, except metacarpal OCs, showed no difference from control in therapeutic doses. There was a highly significant reduction in complete metacarpal OCs of both doses of carbamazepine and $1 / 4 \mathrm{LD}_{50}$ of lamotrigine, in comparison with the control, but there was a highly significant increase in both doses of lamotrigine in comparison with corresponding doses of carbamazepine. Similarly, there was a highly significant reduction in complete metatarsal OCs in both $1 / 4 \mathrm{LD}_{50}$ doses in comparison with the control. No significant difference was recorded in complete metatarsal OCs of therapeutic dose of lamotrigine and a highly significant increase in $1 / 4 \mathrm{LD}_{50}$ dose in comparison with corresponding doses of carbamazepine.
\end{abstract}


Visceral findings: no abnormalities were detected among fetuses in therapeutic doses of treated groups. Fetuses of $1 / 4 \mathrm{LD}_{50}$ treated groups showed internal abnormalities in heads cross sections, while other levels showed no difference from control. Conclusion: lamotrigine in therapeutic dose can be used safely by epileptic pregnant females.

Keywords: antiepileptic drugs, carbamazepine, lamotrigine, teratogenicity in female pregnant rats.

Corresponding author: Saly Y. Abdel Hameed, Department of forensic medicine and toxicology, faculty of medicine, Assiut University, Egypt

email:saso8765@yahoo.com

\section{INTRODUCTION}

Antiepileptic drugs (AEDs) are used in the treatment or prevention of convulsions. They are designed to modify the structures and processes involved in seizure development seizure (neurons, ion channels, receptors, glia and inhibitory or excitatory synapses) which are modified to favor inhibition over excitation to stop or prevent seizure activity. They are also used extensively to treat multiple nonepilepsy disorders, both in neurology and psychiatry (Landmark, 2008).

Number of commercially available AEDs has increased steadily. Although this may complicate management choices, but it also offers new options to individualize treatment more effectively. Each of the available AEDs differs in many clinically relevant properties (spectrum of efficacy in different seizure types, adverse effects, pharmacokinetics, susceptibility to cause or be a target of clinically important drug-drug interactions, ease of use and cost) (Perucca, 2005).

Conventional or old generation of antiepileptic drugs generally inhibit sodium currents e.g. carbamazepine (Czapinski et al., 2005).
Carbamazepine (CZB) reduces the propagation of abnormal impulses in the brain by blocking sodium channels, thereby inhibiting the generation of repetitive action potentials in the epileptic focus (Farber et al., 2002). Novel or new generation of antiepileptic drugs e.g. lamotrigine (Czapinski et al., 2005). Lamotrigine (LTG) is a triazine compound that is chemically unrelated to any of the other AEDs. It was developed as an antifolate agent based on a theory that the mechanism of some AEDs is related to their antifolate property (Aldenkamp et al., 2003).

Skeletal ossification is generally considered to be an indicator of developmental maturity. In rats, it normally begins during the $\mathbf{1 7}^{\text {th }}$ day after conception rapidly followed by the ossification of the mandible and ribs, adhering to a precise time schedule (Walker and Wirtschafter, 1957). The skeletal system develops from mesoderm either in membrane (intramembranous osteogenesis) or in cartilage (endochondral osteogenesis). Several investigators studied skeletal ossification during pre-and postnatal development in rats (Fritz and Hess, 1970 and Aliverti et al., 1979). 
Ossification of the axial skeleton at birth is used as an indicator of the degree of developmental retardation. Delayed ossification at a given time near term indicates none specific retardation of fetal growth and development. Thus, evaluation of skeletal maturity is an important criterion in teratological studies as well as persistent anomalies in ossification which are best observed several days after birth (Fritz and Hess, 1970). Unlike other medications, AEDs cannot be withdrawn even when pregnancy is planned, since uncontrolled seizures may be harmful to the mother as well as to the fetus. This risk must be balanced against the teratogenic risk (Tomson and Battino, 2008).

\section{AIM OF THE STUDY}

It was designed to study possible teratogenic effects of AEDs by comparing one of the old (carbamazepine) with one of the new generation (lamotrigine) to detect AEDs that can be used safely by epileptic pregnant females.

\section{MATERIAL \& METHODS}

This study is a randomized single blind control trial.

A. Antiepileptic drugs:

Carbamazepine (Tegratol)

- Is an old generation AED obtained from NOVARTIS -Egypt

- It is present in the form of syrup $20 \mathrm{mg} / \mathrm{ml}$.

- Human therapeutic dose $\rightarrow$ 15$25 \mathrm{mg} / \mathrm{kg} /$ day; adults can tolerate a daily dose of 1-2 grams in two divided doses (Porter and Meldrum, 2004).
IIa group received the therapeutic dose $=18 \mathrm{mg} /$ day $\approx 0.9 \mathrm{ml}(0.45 \mathrm{ml}$ twice/day) (Paget and Barnes, 1964).

- IIb group received $1 / 4 \mathrm{LD}_{50}=97$ $\mathrm{mg} / \mathrm{kg} \approx 5 \mathrm{ml}(2.5 \mathrm{ml}$ twice/day $)$ (Anon, 2013a).

Lamotrigine (lamotrin):

- Is a new generation AED obtained from APAPEX for pharmaceuticals - Egypt.

- It is present in the form of tablets $100 \mathrm{mg}$.

- Human therapeutic dose $\rightarrow$ 225-375 mg/day in two divided doses.

- IIIa group received therapeutic dose $=5.4 \mathrm{mg} /$ day of lamotrigine dissolved in $0.5 \mathrm{ml}$ normal saline $(0.25$ $\mathrm{ml}$ twice/day) (Paget and Barnes, 1964).

- IIIb group received $1 / 4 \mathrm{LD}_{50}=32$ $\mathrm{mg} / \mathrm{kg}$ of lamotrigine dissolved in 3.2 $\mathrm{ml}$ normal saline (1.6 $\mathrm{ml}$ twice/day)

(Anon, 2013b).

B. Chemicals:

- Distilled water and picric acid $70 \%$ (Morgan chemical works Egypt) were obtained from the lab of Forensic Medicine and Clinical Toxicology Department, Faculty of Medicine, Assiut University.

- Glycerin $\quad 100 \% \quad$ (El-Naser Company, Egypt).

- Potassium hydroxide $(\mathrm{KOH})$ 1\% (El-Gomhoria company, Egypt).

- Potassium carbonate 1\% (ElGomhoria company, Egypt)..

- Alizarin red (Merck, Germany).

- Ethyl alcohol 95\% (El-Naser company, Egypt).

- Formalin 10\%

(ElGomhoriacompany, Egypt).

- Normal saline $0.9 \% \quad$ (ElGomhoria company, Egypt).

C. ANIMALS: 
120 pregnant rats were purchased from animal house of faculty of medicine, Assiut University. They were housed in capacious cages with natural ventilation at room temperature $\left(37^{\circ} \mathrm{C}\right)$. They received tap water and food (rodent pellets) ad libitum.

Day zero of gestation (GD0) was identified after a successful mating which was known by vaginal redness and slight swelling on the following morning (Padmanabhan et al.,2003).

They classified randomly into six groups; each group contained 20 pregnant female rats.

- Control groups (I) further subdivided into Ia and $\mathrm{Ib}$ (20 rats each) according to intake as follows:

- Ia $\rightarrow$-ve control, received nothing.

- Ib $\rightarrow+$ +ve control, received normal saline.

- Treated groups:

-Carbamazepine group (II) further subdivided into IIa and IIb according to dose as follows:

- IIa $\rightarrow$ received therapeutic dose $(18 \mathrm{mg} / \mathrm{kg})$.

$\begin{array}{lllll}\text { - IIb } \rightarrow \text { received } & 1 / 4 & \mathrm{LD}_{50}\end{array}$ $(97 \mathrm{mg} / \mathrm{kg})$.

-Lamotrigine group (III) further subdivided into IIIa and IIIb according to dose as follows:

- IIIa $\rightarrow$ received therapeutic dose $(5.4 \mathrm{mg} / \mathrm{kg})$.

- IIIb $\rightarrow$ received $1 / 4 \quad \mathrm{LD}_{50}$ (32mg/kg).

Saline or drugs were given using a gastric tube from $6^{\text {th }}$ day up to the $19^{\text {th }}$ day of gestation. They were then killed by cervical dislocation (after inhalation anesthesia) on the $20^{\text {th }}$ day of gestation, dissected and fetuses were exposed.
1. SKELETAL SUBGROUP: were eviscerated and preserved in $95 \%$ ethyl alcohol for skeletal staining. According to modified Dawson's technique, fetal skeletons were stained as follows: (Richmond and Bennett, 1938):

- Fetuses were eviscerated through a small midline abdominal incision and fixed in $95 \%$ alcohol. The incision permits the free access of reagent.

Specimens were rinsed in $1 \%$ potassium carbonate for 4 weeks.

- Soft parts were cleared by immersing the specimens in $1 \% \mathrm{KOH}$ for 10 days, until the bones were clearly visible through the soft tissue.

- Staining was done by immersing the specimens in freshly prepared $0.1 \%$ aqueous solution of alizarin red $\mathrm{S}$ to which 6-10 drops of $1 \% \mathrm{KOH}$ were added.

- Specimens were depolarized by immersion in an aqueous solution of $20 \%$ glycerin and $1 \% \mathrm{KOH}$ until the soft tissues became entirely transparent showing the ossified skeleton stained deeply red.

- When bones were clearly visible, specimens were transferred through several concentrations of 50 , 70,80 and $90 \%$ solution of glycerin in water, and lastly was preserved in $100 \%$ glycerin to which few drops of formaldehyde solution were added to prevent fungal growth. Skeletal system was then examined.

Skeletal system examination included the following:

I. Bones of axial skeleton:

- Skull (craniofacial bones).

- Vertebral column (thoracic, lumbar, sacral and caudal vertebrae).

- Sternum. 
- Ribs.

II. Bones of the appendicular skeleton: -

- Clavicle.

- Scapula.

- Forelimbs (humerus, radius, ulna and carpal, metacarpals and phalanges).

- Hindlimbs (coxal bone, femur, tibia, fibula and tarsal, metatarsal and phalanges).

Ossification was considered complete, incomplete or absent. Incomplete ossification was identified when the center was either small or faintly stained (Kimmel et al., 1982). For statistical analysis, Ossification centers (OCs) (complete, incomplete or absent) of craniofacial bones, vertebral centers (thoracic, lumbar, sacral and caudal), metacarpal and metatarsal of all fetuses of each group were counted. In addition to the total number of complete, incomplete and absent OCs in each group that were recorded and expressed as a percent from the total number of centers.

Mean and standard deviation values for the number of complete OCs being an index for proper ossification were calculated according to Ibrahim (2003), as follows:

Number of complete OCs $\%=$

Total number of complete OCs / total number of OCs X 100).

Mean complete $\mathrm{OCs}=$

Total number of complete OCs in each group / number of fetuses in each group.

Number of incomplete OCs $\%=$

Total number of incomplete OCs / total number of OCs X 100).

Number of absent OCs $\%=$

Total number of absent OCs / total number of OCs X 100).

\section{VISCERAL SUBGROUP:} were fixed in Bouin's solution (aqueous saturated solution of picric acid $70 \%$ formalin $25 \%$, glacial acetic acid 5\%) for visceral examination (Drury and Wallington, 1980). Internal organs were studied by using the Wilson's razor blade technique. The whole fetuses were sectioned (3-5mm) in cranio-caudal direction (cross sections) as in figure (A) and the slices sequentially examined under the microscope (connected to digital camera) for any gross visceral abnormalities (Wilson, 1964). 


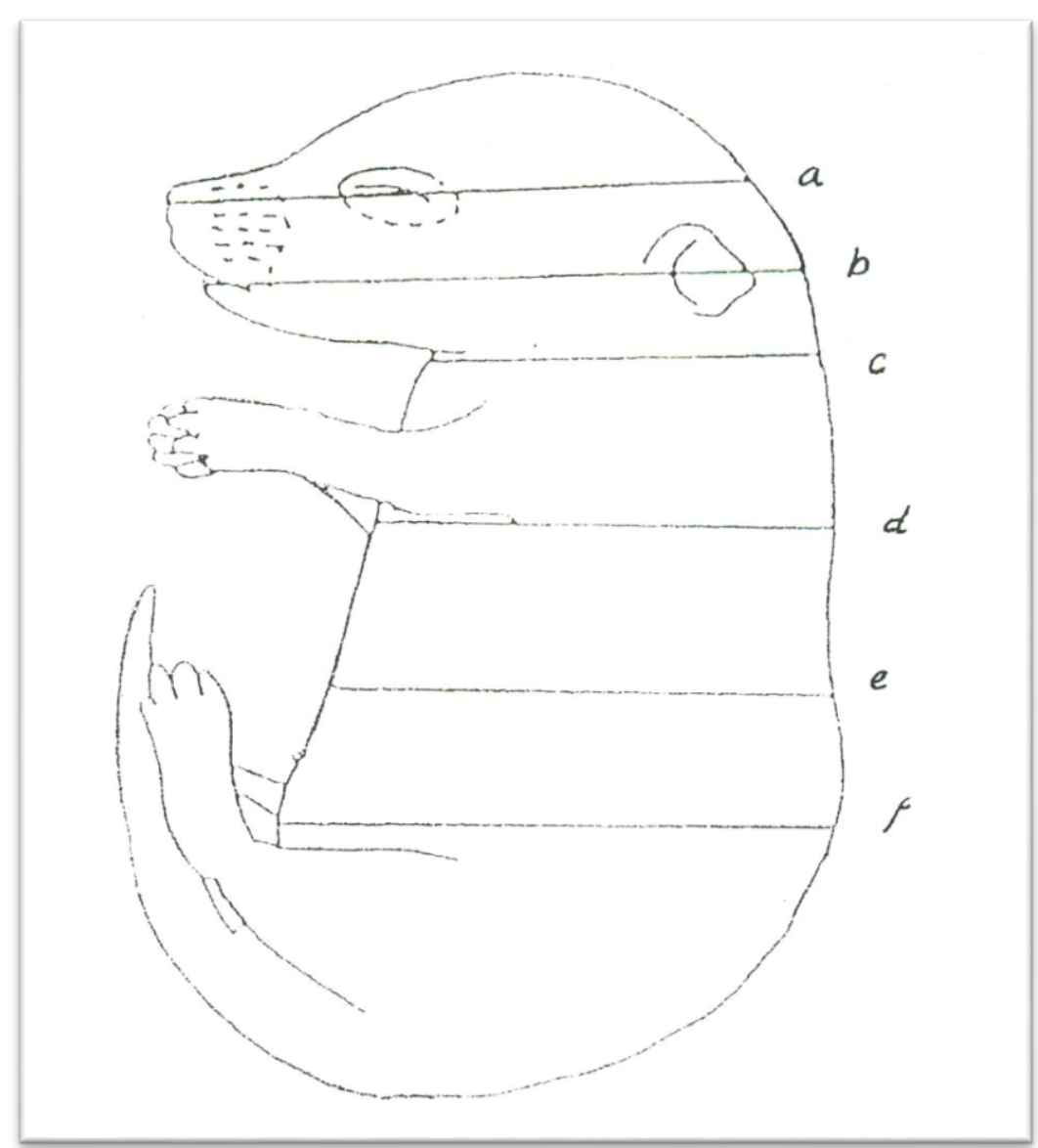

Figure (1): A diagram showing the sites of the Wilson's sections taken in a 20-days old rat offspring (Wilson, 1964). (a) through the eyeball; (b) through the ear and mouth; (c) cranial to the forelimbs; (d) caudal to the forelimbs; (e) in the abdomen cranial to the umbilicus; (f) in the abdomen caudal to the umbilicus.

\section{Statistical analysis:}

The Statistical Package for Social Sciences (SPSS) version 16.0 was used in data analysis.

Comparisons for the means and the significance were made by t-student's test. The level of significance was set at $\mathrm{P}<0.05$.

\section{RESULTS}

This study detects the teratogenicity of 2 antiepileptic drugs (AEDs); Carbamazepine (old generation) and Lamotrigine (new generation). G II a and GIII received Carbamazepine and Lamotrigine their therapeutic dose respectively. GII b and $G$ III $b$ received $1 / 4 \quad L_{50}$ of
Carbamazepine and Lamotrigine respectively.

Skeletal anomalies:

Fetal skeletons were examined where OCs were used as indicators of fetal development. Examination included the following:

I. Bones of axial skeleton:

- Table (1) and figure (2) represent the effect of AEDs on craniofacial OCs (13 bones were examined in each rat) a highly statistical significant reduction $(\mathrm{P}<0.001)$ in the mean of complete craniofacial OCs of all AEDs treated groups in comparison with the control was observed, incomplete centers were detected in all groups (photos: 1, 
2, 3, 4, 5, 6, 7, 8, 9, 10, 11, 12 and 13), while absent centers were recorded only in group III $b$ (photo.14).

By comparing the mean of complete craniofacial OCs in groups II a and III a, no significant difference was revealed. On the other hand, the comparison between groups II $\mathrm{b}$ and III $b$ revealed a highly significant decrease $(\mathrm{P}<0.001)$

- Table (2) and figure (3) represent the effect of maternal AEDs administration on vertebral OCs (25 bones were examined in each rat). There is a highly statistical significant $(\mathrm{P}<0.001)$ reduction in the mean of complete vertebral ossification centers of II $b$ and III $b$ groups, in comparison with control group, while there is no statistically significant difference in those of G II a and G III a when compared with control group, incomplete centers were not detected in all groups except in groups II b (photo. 15 and 16), while absent centers were recorded only in groups III b (photo.14).

By comparing the mean of complete vertebral OCs in groups II a and III a, no significant difference was revealed. On the other hand, the comparison between groups II $\mathrm{b}$ and III $b$ revealed a highly significant decrease $(\mathrm{P}<0.001)$

- Table (3) and figure (4) represent the effect of maternal AEDs administration on thoracic OCs (12 bones were examined in each rat). There is a very highly statistical significant reduction in the mean of complete thoracic OCs in G IIb and G IIIb $(\mathrm{p}<0.001)$ in comparison with the control group, while there is no statistically significant difference in mean of II a and III a groups when compared with control group. The incomplete centers were not detected in all groups except in group IIb (photo.15 and 16), while absent centers were recorded only in group III b (photo.14)

By comparing the mean of complete thoracic OCs in groups II a and III a, no significant difference was revealed. On the other hand, the comparison between groups II b and III $b$ revealed a highly significant decrease $(\mathrm{P}<0.001)$.

- Table (4) and figure (5) represent the effect of maternal AEDs administration on lumbar OCs (6 bones were examined in each rat). There is a very highly statistical significant $(\mathrm{P}<0.001)$ reduction in the mean of lumbar ossification centers of $\mathrm{IIb}$ and IIIb groups, in comparison with control group, while there is no statistically significant difference in mean of II a and III a groups when compared with control group. There are incomplete centers were detected in group II b (photo.15 and 16), while absent centers were recorded in IIIb (photo. 14).

By comparing the mean of complete lumbar OCs in groups II a and III a, no significant difference was revealed. On the other hand, the comparison between groups II $b$ and III $b$ revealed a highly significant decrease $(\mathrm{P}<0.001)$

- Table (5) and figure (6) represent the effect of maternal AEDs administration on sacral OCs (4 bones were examined in each rat). There is a very highly statistical significant $(\mathrm{P}<0.001)$ reduction in the mean of complete sacral ossification centers of $\mathrm{IIb}$ and IIIb groups in comparison with control group, while there is no statistically significant difference in mean of II a and III a groups 
compared with control group. The incomplete centers were not detected in all groups except in group II b (photo.15 and 16), while absent centers were recorded only in group III b (photo.14).

By comparing the mean of complete vertebral OCs in groups II a and III a, no significant difference was revealed. On the other hand, the comparison between groups II $\mathrm{b}$ and III $\mathrm{b}$ revealed a highly significant decrease $(\mathrm{P}<0.001)$

- Table (6) and figure (7) represent the effect of maternal AEDs administration on caudal OCs ( 3 bones were examined in each rat). There is a very highly statistical significant $(\mathrm{P}<0.001)$ reduction in the mean of complete caudal ossification centers of II $b$ and III $b$ group, in comparison with control group, while there is no statistically significant difference in mean of IIa and IIIa groups when compared with control group. Incomplete centers were detected in groups IIb (photo.15 and 16), while absent centers were recorded only in group IIIb (photo.14).

By comparing the mean of complete caudal OCs in groups II a and III a, no significant difference was revealed. On the other hand, the comparison between groups II $b$ and III $\mathrm{b}$ revealed a highly significant decrease $(\mathrm{P}<0.001)$

The sternum:

The Sternum was completely ossified in all groups except III b where 6 out of 37 fetuses (16.2\%) showed complete absence of OCs.

The ribs:

All ribs (13 pairs in each fetus) were completely ossified in groups I, IIa and III a; while in group IIb, incomplete ossifications were noticed in 8 out of 60 fetuses $(13.3 \%)$ (photo.15, 16 and 17). Other anomalies were recorded in group IIb in the form of angulations in 6 fetuses $(10.0 \%)$ and short ribs in 4 fetuses $(6.7 \%)$ and in group III b absent OCs was noticed in 6 out of 37 fetuses (16.2\%) (photo.14).

II. The Appendicular Skeleton:

1. The clavicle was completely ossified in all groups except in group IIIb where absent OCs was noticed in 6 out of 37 fetuses (16.2\%) (photo.14).

2. The scapula was completely ossified in groups I, IIa and, IIIa, while IIb showed incomplete ossification in 8 out of 60 fetuses (13.3\%) (photo.18), and IIIb showed absent OCs in 6 out of 37 fetuses (16.2\%) (photo.14).

3. The forelimbs:

The humerus, radius and ulna were completely ossified in groups I, IIa and IIIa; while IIb showed incomplete ossification in 8 out of 60 fetuses (13.3\%) (photo. 18 and 19) and IIIb showed absent OCs in 6 out of 37 fetuses (16.2\%) (photo. 14).

- Table (7) and figure (8) represent the effect of maternal AEDs administration on metacarpal OCs (3 bones were examined in each rat). There is a very highly statistical significant $(\mathrm{P}<0.001)$ reduction in the mean of complete metacarpal ossification centers of IIa, IIb and III b groups, in comparison with control group, while there is no statistically significant difference in mean of III a group when compared with control group, incomplete centers were detected in groups II a, II b (photo. 18 and 19) While, absent centers were recorded in groups II $b$ and III b (photo.14). 
By comparing the mean of complete metacarpal OCs in groups II a and III a, there is a highly significant difference $(p<0.001)$ was revealed. However, the comparison between groups II $b$ and III $b$ revealed a highly significant decrease $(\mathrm{P}<0.001)$.

4. Hind limbs:

Ileum and ischium were completely ossified in all groups except IIb where 6 out of 60 fetuses (10.0\%) (photo.19) showed incomplete ossification and IIIb where 6 out of 37 fetuses showed absent ossification (16.2\%) (photo. 14).

Femur, tibia and fibula were completely ossified in groups I, IIa and IIIa. In IIb 6 out of 60 fetuses (10.0\%) (photo.17) showed incomplete ossification of femur (photo.19) and 11 out of 60 fetuses (18.3\%) showed incomplete ossification of tibia; while in group IIIb 6 out of 37 fetuses (16.2\%) showed incomplete ossification of fibula.

- Table (8) and figure (9) represent the effect of maternal AEDs administration on metatarsal OCs (3 bones were examined in each rat). There is a very highly statistical significant $(\mathrm{P}<0.001)$ reduction in the mean of complete metatarsal ossification centers of II $b$ and III $b$ groups, in comparison with control group, while there is no statistically significant difference in mean of II a and III a groups when compared with control group, incomplete centers were detected in groups II b(photo. 18 and 20), while absent centers were recorded only in group III b (photo.14)..

By comparing the mean of complete metatarsal OCs in groups II a and III a, no significant difference was revealed. On the other hand, the comparison between groups II $b$ and III $b$ revealed a highly significant decrease $(\mathrm{P}<0.001)$

Visceral Findings:

The visceral subgroup (2/3 of fetuses) was kept in bouin's solution. Internal organs were examined using Wilson's razor blade technique. No abnormalities were detected in fetuses of groups I, II a and III a. Fetuses of groups II $b$ and III $b$ showed abnormalities in the heads only Abnormalities at the level of the head were as follows:

- Carbamazepine 1/4 LD50 (IIb):

- Abnormalities were detected in 14 out of 119 fetuses $(12 \%)$.

The brain of 7 fetuses showed dilatation of the lateral ventricle (photos. 31 and 32), shrinkage (photo. 33) and degenerative (necrotic) changes (photos. 32 and 34). .

The eyes of 5 fetuses showed delayed development of one eye (photo. 34) and both eyes (photos. 31 and 32).

The palate of 2 fetuses showed moderate degree of smoothness (photo. 35).

- Lamotrigine 1/4 LD50 (IIIb):

Abnormalities were detected in all 74 fetuses where the brain showed areas of softening, indicating degeneration (photo. 36). 


\section{Skeletal Evaluation}

I) Axial Skeleton:

Table (1): Effect of maternal AEDs administration on craniofacial ossification centers ( 13 bones) of albino rat fetuses

\begin{tabular}{|c|c|c|c|c|c|c|c|c|c|}
\hline \multirow[t]{2}{*}{ Groups } & \multirow{2}{*}{$\begin{array}{l}\text { No. of } \\
\text { Fetuses }\end{array}$} & \multirow{2}{*}{$\begin{array}{l}\text { Total } \\
\text { No. of } \\
\text { centers }\end{array}$} & \multirow{2}{*}{$\begin{array}{l}\text { Mean } \pm \text { SD of } \\
\text { complete } \\
\text { centers }\end{array}$} & \multicolumn{2}{|c|}{$\begin{array}{l}\text { No of } \\
\text { complete } \\
\text { centers }\end{array}$} & \multicolumn{2}{|c|}{$\begin{array}{l}\text { No of } \\
\text { incomplete } \\
\text { centers }\end{array}$} & \multicolumn{2}{|c|}{$\begin{array}{ll}\text { No of } \\
\text { absent } \\
\text { centers }\end{array}$} \\
\hline & & & & No & $\%$ & No & $\%$ & No & $\%$ \\
\hline I & 68 & 884 & $13.0 \pm 0.0$ & 884 & 100 & 0 & 0 & 0 & 0.0 \\
\hline II a & 61 & 793 & $12.0 \pm 1.1^{* * *}$ & 732 & 92.3 & 61 & 7.7 & 0 & 0.0 \\
\hline II b & 60 & 780 & $11.0 \pm 0.8^{* * *}$ & 660 & 84.6 & 120 & 15.4 & 0 & 0.0 \\
\hline III a & 47 & 611 & $\begin{array}{l}12.3 \pm 0.8^{* * * *} \\
\text { §NS }\end{array}$ & 580 & 94.9 & 31 & 5.1 & 0 & 0.0 \\
\hline III $b$ & 37 & 481 & $\begin{array}{l}9.0 \pm 1.2^{* * * *} \\
\S_{* * * *}\end{array}$ & 333 & 69.2 & 68 & 14.1 & 80 & 16.7 \\
\hline
\end{tabular}

Results are shown as mean \pm SD.

No: Number

- \%; The percentage calculated from number of incomplete centers / total number of centers X 100

* Comparison between control versus each treated group, -§ Comparison between carbamazepine versus lamotrigine in both dose

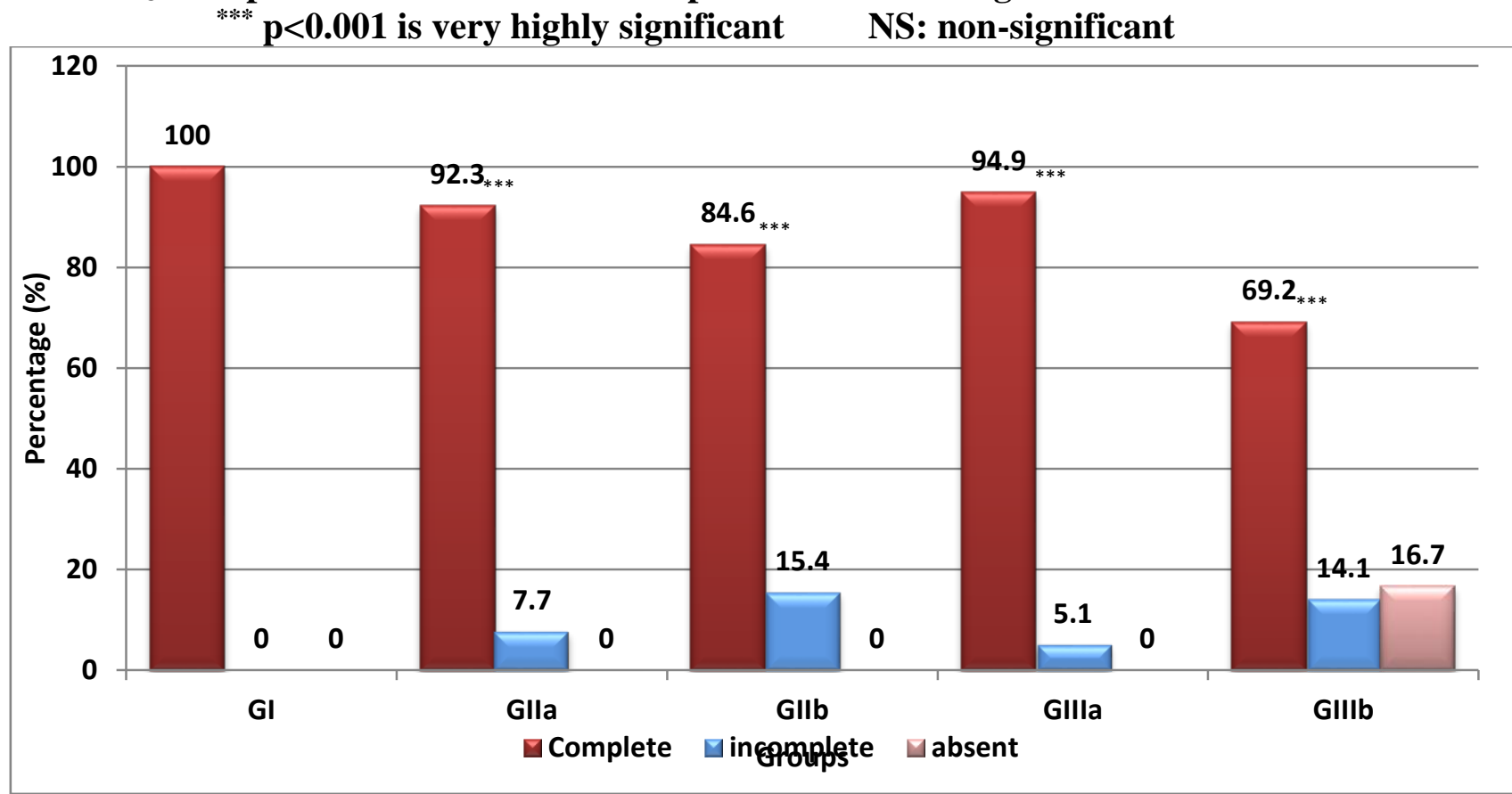

Figure (1): Effect of maternal AEDs administration on craniofacial ossification centers of albino rat fetuses 
Table (2): Effect of maternal AEDs administration on vertebral ossification centers ( 25 bones) of albino rat fetuses

\begin{tabular}{|c|c|c|c|c|c|c|c|c|c|}
\hline \multirow[t]{2}{*}{ Groups } & \multirow{2}{*}{$\begin{array}{l}\text { No. of } \\
\text { Fetuse } \\
\text { s } \\
\end{array}$} & \multirow{2}{*}{$\begin{array}{l}\text { Total } \\
\text { No } \\
\text { of } \\
\text { centers }\end{array}$} & \multirow[t]{2}{*}{$\begin{array}{l}\text { Mean } \pm \text { SD } \\
\text { of complete } \\
\text { centers }\end{array}$} & \multicolumn{2}{|c|}{$\begin{array}{l}\text { No of } \\
\text { complete } \\
\text { centers }\end{array}$} & \multicolumn{2}{|c|}{$\begin{array}{l}\text { No of } \\
\text { incomplete } \\
\text { centers }\end{array}$} & \multicolumn{2}{|c|}{$\begin{array}{l}\text { No of } \\
\text { absent } \\
\text { centers }\end{array}$} \\
\hline & & & & No & $\%$ & No & $\%$ & No & $\%$ \\
\hline I & 68 & 1700 & $25 \pm 0$ & 1700 & 100 & 0 & 0 & 0 & 0 \\
\hline IIa & 61 & 1525 & $25 \pm 0$ & 1525 & 100 & 0 & 0 & 0 & 0 \\
\hline IIb & 60 & 1500 & $12.2 \pm 0.8^{* * * *}$ & 735 & 49 & 765 & 51 & 0 & 0 \\
\hline IIIa & 47 & 1175 & $25 \pm 0^{\S N S}$ & 1175 & 100 & 0 & 0 & 0 & 0 \\
\hline IIIb & 37 & 925 & $20.8 \pm 1.7^{* * * *}$ & 771 & 83.4 & 0 & 0 & 154 & 16.6 \\
\hline
\end{tabular}

Results are shown as: mean \pm SD of each group. No: Number

$-\%$ : The percentage calculated from number of incomplete centers / total number of centers X 100

- * Comparison control versus each treated group.

- § Comparison between carbamazepine versus lamotrigine in both doses

${ }^{* * * *} \mathbf{p}<0.001$ is highly significant NS: non-significant

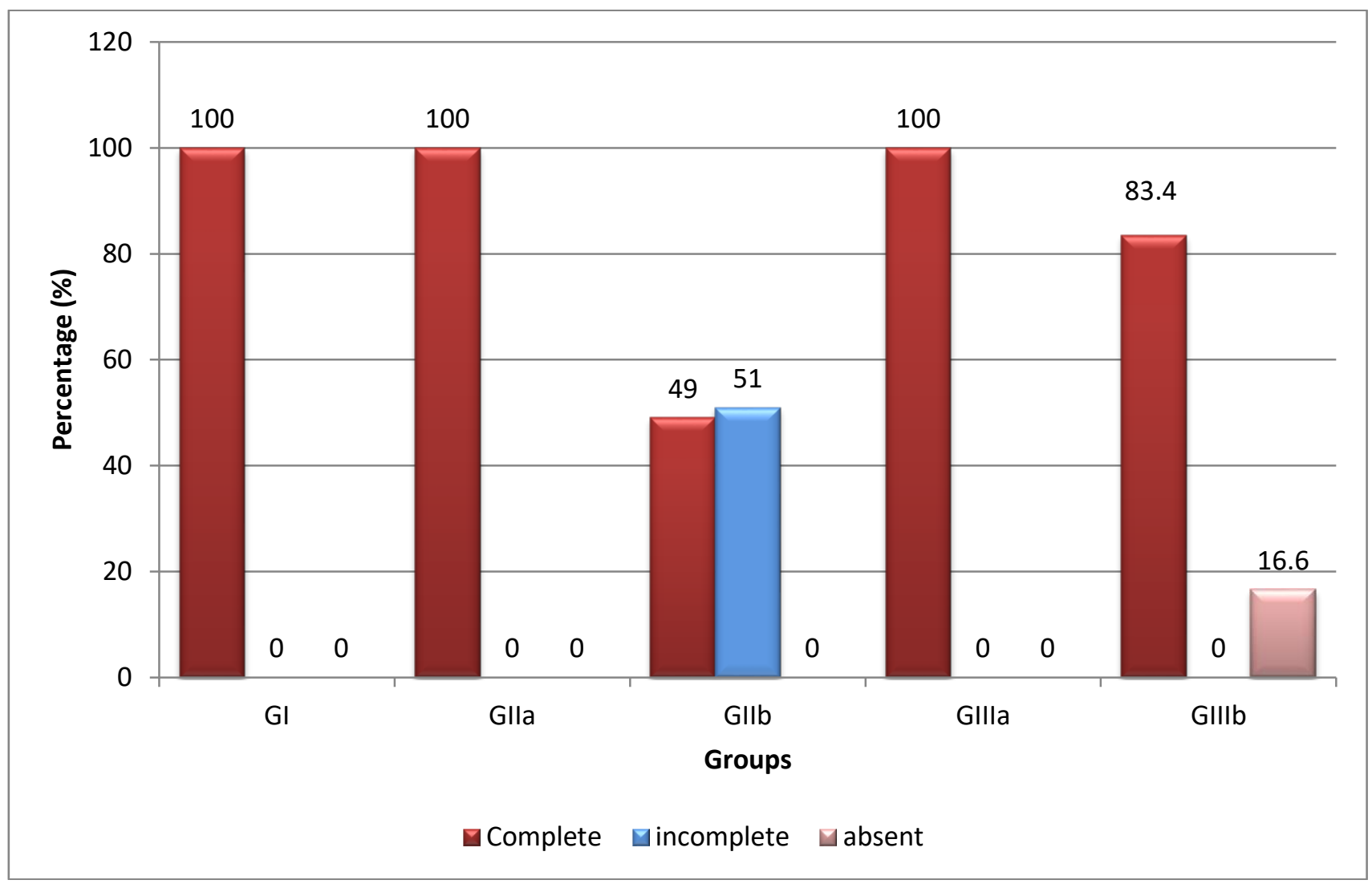


Figure (2): Effect of maternal AEDs administration on vertebral ossification centers of albino rat fetuses.

Table (3): Effect of maternal AEDs administration on thoracic. ossification centers of albino rat fetuses.

\begin{tabular}{|c|c|c|c|c|c|c|c|c|c|}
\hline \multirow[t]{2}{*}{ Groups } & \multirow{2}{*}{$\begin{array}{l}\text { No. } \\
\text { of } \\
\text { Fetuses }\end{array}$} & \multirow{2}{*}{$\begin{array}{l}\text { Total } \\
\text { No of } \\
\text { centers }\end{array}$} & \multirow{2}{*}{$\begin{array}{l}\text { Mean } \pm \text { SD of } \\
\text { complete } \\
\text { centers }\end{array}$} & \multicolumn{2}{|c|}{$\begin{array}{l}\text { No of } \\
\text { complete } \\
\text { centers }\end{array}$} & \multicolumn{2}{|c|}{$\begin{array}{l}\text { No of } \\
\text { incomplete } \\
\text { centers }\end{array}$} & \multicolumn{2}{|c|}{$\begin{array}{l}\text { No of } \\
\text { absent } \\
\text { centers }\end{array}$} \\
\hline & & & & No & $\%$ & No & $\%$ & No & $\%$ \\
\hline $\begin{array}{l}\text { G } \\
\text { I(control })\end{array}$ & 68 & 816 & $12.0 \pm .00$ & 816 & 100.0 & 0 & 0.0 & 0 & 0.0 \\
\hline G IIa & 61 & 732 & $12.0 \pm 0.0$ & 732 & 100.0 & 0 & 0.0 & 0 & 0.0 \\
\hline G IIb & 60 & 720 & $5.2 \pm 0.7^{* * *}$ & 315 & 43.8 & 405 & 56.2 & 0 & 0.0 \\
\hline G IIIa & 47 & 564 & $12.0 \pm 0.0^{\S \mathrm{NS}}$ & 564 & 100.0 & 0 & 0.0 & 0 & 0.0 \\
\hline G IIIb & 37 & 444 & $\begin{array}{l}10.0 \pm 1.4^{* * *} \\
\S * * *\end{array}$ & 370 & 83.3 & 0 & 0.0 & 74 & 16.7 \\
\hline
\end{tabular}

Results are shown as: mean \pm SD of each group. No: Number

-\%: The percentage calculated from number of incomplete centers / total number of centers X 100

- * Comparison control versus each treated group.

- § Comparison between carbamazepine versus lamotrigine in both doses
${ }^{* * * *} \mathbf{p}<0.001$ is highly significant
NS: non-significant

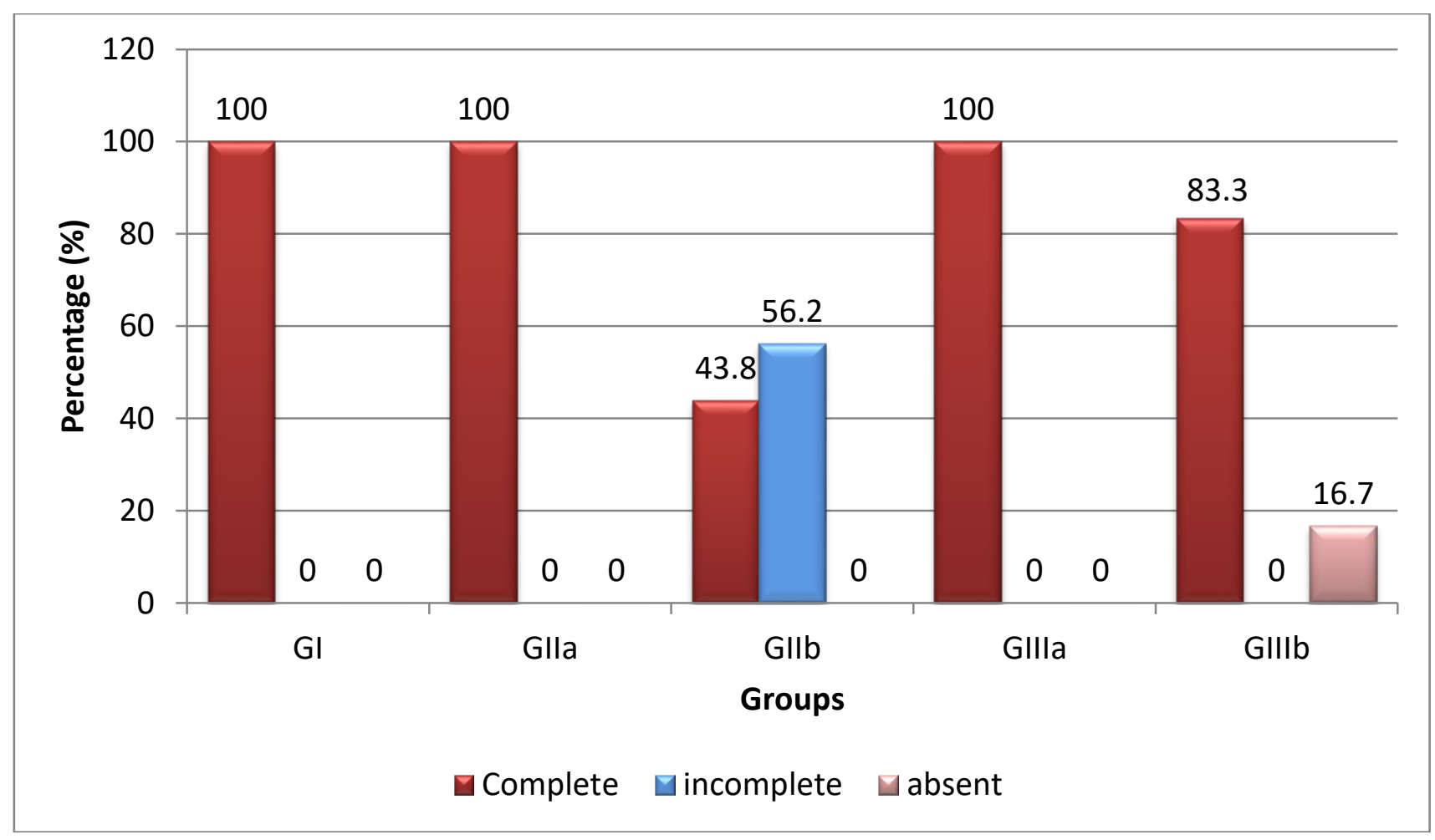

Figure (3): Effect of maternal AEDs administration on thoracic ossification centers of albino rat fetuses 
Table (4): Effect of maternal AEDs administration on lumbar ossification centers of albino rat fetuses (L1-6)

\begin{tabular}{|c|c|c|c|c|c|c|c|c|c|}
\hline \multirow[t]{2}{*}{ Groups } & \multirow[t]{2}{*}{$\begin{array}{l}\text { No. of } \\
\text { Fetuses }\end{array}$} & \multirow{2}{*}{$\begin{array}{l}\text { Total } \\
\text { No of } \\
\text { centers }\end{array}$} & \multirow{2}{*}{$\begin{array}{l}\text { Mean } \pm \text { SDof } \\
\text { complete } \\
\text { centers }\end{array}$} & \multicolumn{2}{|c|}{$\begin{array}{ll}\text { No of } \\
\text { complete } \\
\text { centers }\end{array}$} & \multicolumn{2}{|c|}{$\begin{array}{l}\text { No of } \\
\text { incomplete } \\
\text { centers }\end{array}$} & \multicolumn{2}{|c|}{$\begin{array}{ll}\text { No } & \text { of } \\
\text { absent } & \\
\text { centers } & \\
\end{array}$} \\
\hline & & & & No & $\%$ & No & $\%$ & No & $\%$ \\
\hline $\begin{array}{l}\mathbf{G} \\
(\text { control) }\end{array}$ & 68 & 408 & $6.0 \pm 0.0$ & 408 & 100.0 & 0 & 0.0 & 0 & 0.0 \\
\hline G II a & 61 & 366 & $6.0 \pm 0.0$ & 366 & 100.0 & 0 & 0.0 & 0 & 0.0 \\
\hline GII b & 60 & 360 & $2.62 \pm 0.5^{* * *}$ & 158 & 43.9 & 202 & 56.1 & 0 & 0.0 \\
\hline G III a & 47 & 282 & $6.0 \pm 0.0^{\S N S}$ & 282 & 100.0 & 0 & 0.0 & 0 & 0.0 \\
\hline G III b & 37 & 222 & $\begin{array}{l}5.0 \pm 0.9^{* * * *} \\
\S * * *\end{array}$ & 185 & 83.3 & 0 & 0.0 & 37 & 16.7 \\
\hline
\end{tabular}

Results are shown as: mean \pm SD of each group. No: Number $\%$ : The percentage calculated from number of incomplete centers / total number of centers X 100.

* Comparison control versus each treated group, -§ Comparison between carbamazepine versus lamotrigine in both doses ${ }^{* * * *} \mathbf{p}<0.001$ is highly significant NS: non-significant 


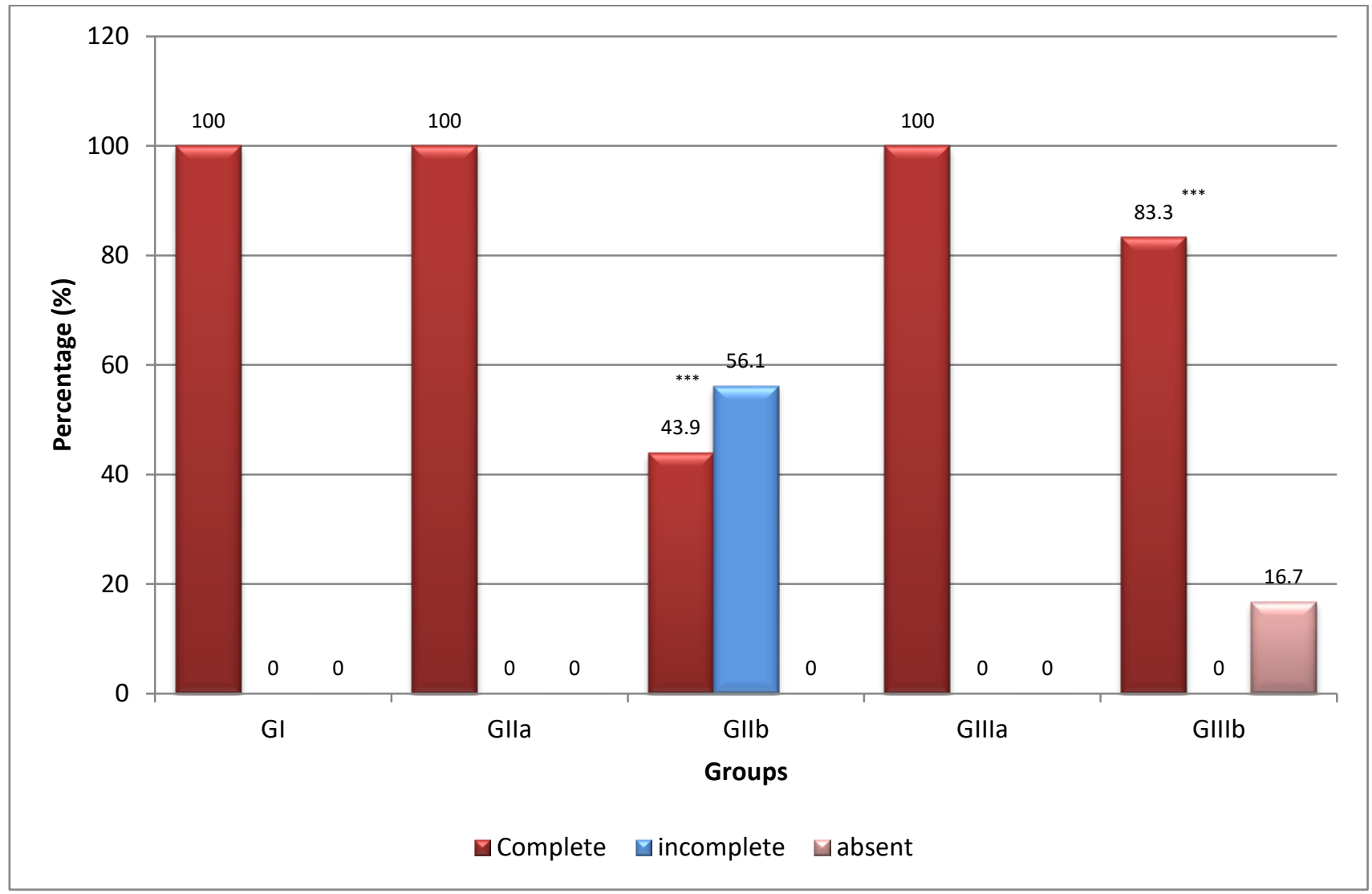

Figure (4): Effect of maternal AEDs administration on lumbar ossification centers of albino rat fetuses

Table (5): Effect of maternal AEDs administration on sacral ossification centers of albino rat fetuses (S1-4):

\begin{tabular}{|c|c|c|c|c|c|c|c|c|c|}
\hline \multirow[t]{2}{*}{ Groups } & \multirow[t]{2}{*}{$\begin{array}{l}\text { No. of } \\
\text { Fetuses }\end{array}$} & \multirow[t]{2}{*}{$\begin{array}{l}\text { Total } \\
\text { No of } \\
\text { centers }\end{array}$} & \multirow{2}{*}{$\begin{array}{l}\text { Mean } \pm \text { SDof } \\
\text { complete } \\
\text { centers }\end{array}$} & \multicolumn{2}{|c|}{$\begin{array}{l}\text { No of } \\
\text { complete } \\
\text { centers }\end{array}$} & \multicolumn{2}{|c|}{$\begin{array}{l}\text { No of } \\
\text { incomplet } \\
\text { e centers }\end{array}$} & \multicolumn{2}{|c|}{$\begin{array}{ll}\text { No } & \text { of } \\
\text { absent } & \\
\text { centers } & \\
\end{array}$} \\
\hline & & & & No & $\%$ & No & $\%$ & No & $\%$ \\
\hline $\begin{array}{l}\mathbf{G} I \\
\text { (control) }\end{array}$ & 68 & 272 & $4.00 \pm 0.0$ & 272 & 100.0 & 0 & 0.0 & 0 & 0.0 \\
\hline G IIa & 61 & 244 & $4.00 \pm 0.0$ & 244 & 100.0 & 0 & 0.0 & 0 & 0.0 \\
\hline G IIb & 60 & 240 & $2.50 \pm 0.9^{* * *}$ & 150 & 62.5 & 90 & 37.5 & 0 & 0.0 \\
\hline G IIIa & 47 & 188 & $4.00 \pm 0.0^{\S N S}$ & 188 & 100.0 & 0 & 0.0 & 0 & 0.0 \\
\hline G IIIb & 37 & 148 & $\begin{array}{l}3.33 \pm 0.8^{* * * *} \\
8_{* * * *}\end{array}$ & 123 & 83.1 & 0 & 0.0 & 25 & 16.9 \\
\hline
\end{tabular}

Results are shown as: mean \pm SD of each group. No: Number

$\%$ : The percentage calculated from number of incomplete centers / total number of centers X 100

* Comparison control versus each treated group.

$\S$ Comparison between carbamazepine versus lamotrigine in both doses

${ }^{* * * *} \mathbf{p}<0.001$ is highly significant NS: non-significant 


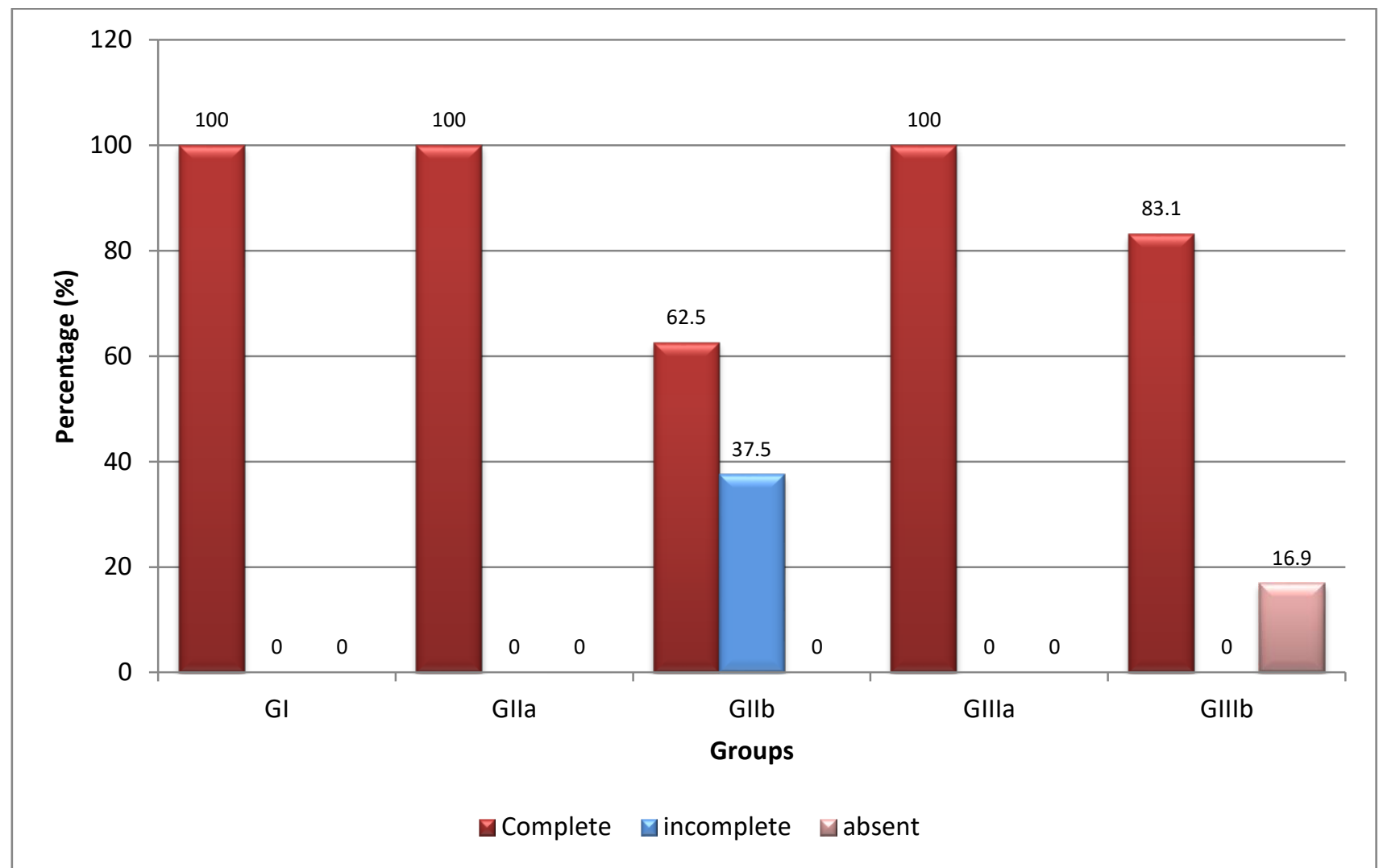

Figure (5): Effect of maternal AEDs administration on sacral ossification centers of albino rat fetuses

Table (6): Effect of maternal AEDs administration on caudal ossification centers of albino rat fetuses $(\mathrm{C} 1-3)$ :

\begin{tabular}{|l|l|l|l|l|l|l|l|l|l|l|}
\hline Groups & \multirow{2}{*}{$\begin{array}{l}\text { No. of } \\
\text { Fetuses }\end{array}$} & $\begin{array}{l}\text { Total } \\
\text { No of } \\
\text { centers }\end{array}$ & $\begin{array}{l}\text { Mean } \\
\text { complete } \\
\text { centers }\end{array}$ & $\begin{array}{l}\text { No } \\
\text { complete } \\
\text { centers }\end{array}$ & \multicolumn{2}{|l|}{$\begin{array}{l}\text { No of } \\
\text { incomplet } \\
\text { e centers }\end{array}$} & \multicolumn{2}{|l|}{$\begin{array}{l}\text { No of } \\
\text { absent } \\
\text { centers }\end{array}$} \\
\hline $\begin{array}{l}\text { G I } \\
\text { (control) }\end{array}$ & 68 & 204 & $3.00 \pm 0.0$ & 204 & 100.0 & 0 & 0.0 & 0 & 0.0 \\
\hline G IIa & 61 & 183 & $3.00 \pm 0.0$ & 183 & 100.0 & 0 & 0.0 & 0 & 0.0 \\
\hline G IIb & 60 & 180 & $1.88 \pm 0.7^{* * *}$ & 113 & 62.8 & 67 & 37.2 & 0 & 0.0 \\
\hline G IIIa & 47 & 141 & $3.00 \pm 0.0^{\S N S}$ & 141 & 100.0 & 0 & 0.0 & 0 & 0.0 \\
\hline G IIIb & 37 & 111 & $\begin{array}{l}2.50 \pm 0.5^{* * *} \\
8_{* * * *}^{* * *}\end{array}$ & 93 & 83.8 & 0 & 0.0 & 18 & 16.2 \\
\hline
\end{tabular}

Results are shown as: mean \pm SD of each group. No: Number

$\%$ : The percentage calculated from number of incomplete centers / total number of centers X 100

-* Comparison control versus each treated group.

- § Comparison between carbamazepine versus lamotrigine in both doses ${ }^{* * * *} \mathbf{p}<0.001$ is very significant

NS: non-significant 


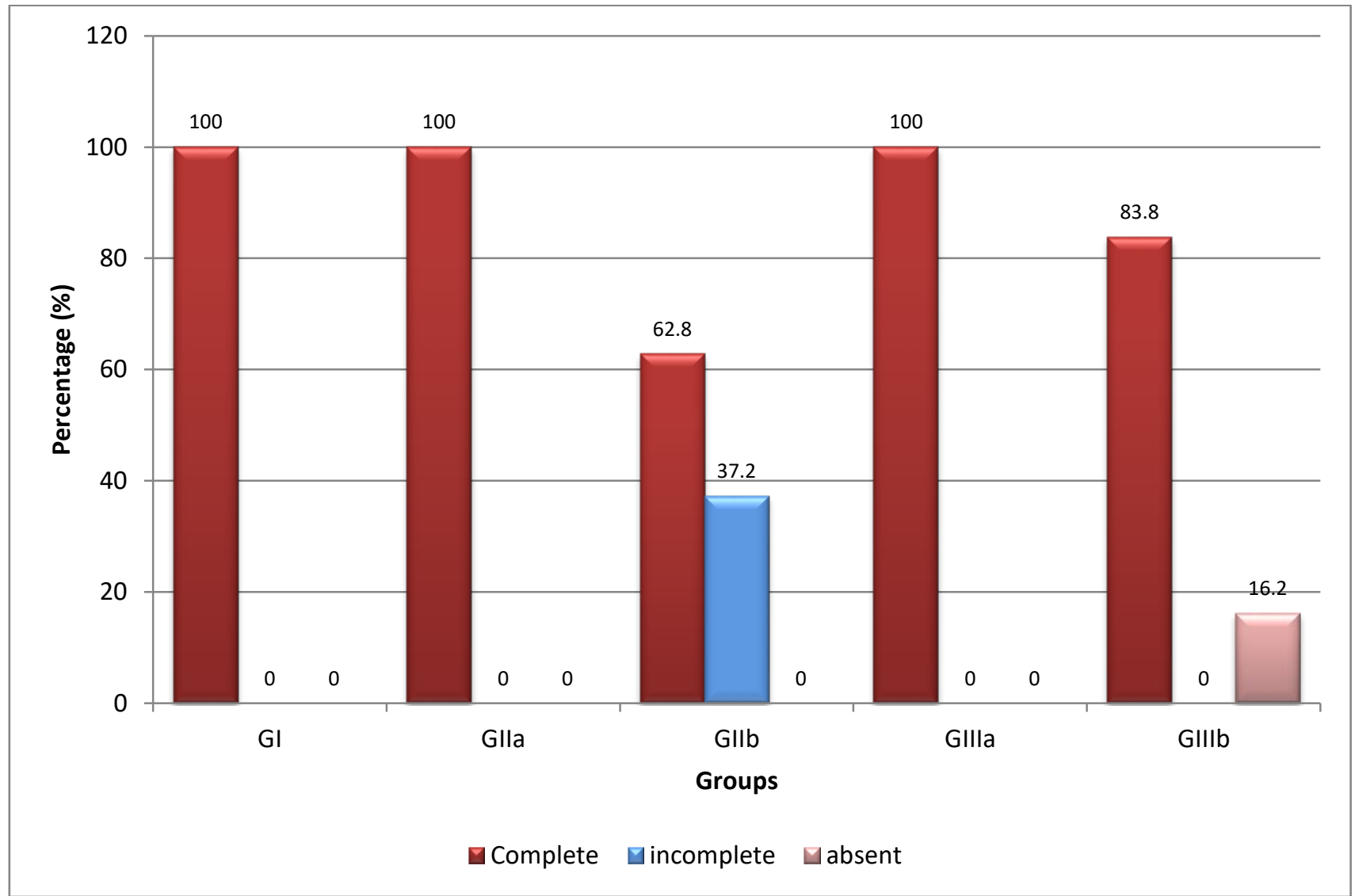

Figure (6): Effect of maternal AEDs administration on caudal ossification centers of albino rat fetuses

\section{Metacarpal centers:}

Table (7): Effect of maternal AEDs administration on metacarpal ossification centers of albino rat fetuses (Mc 1-3)

\begin{tabular}{|c|c|c|c|c|c|c|c|c|c|}
\hline \multirow[t]{2}{*}{ Groups } & \multirow[t]{2}{*}{$\begin{array}{l}\text { No. of } \\
\text { Fetuses }\end{array}$} & \multirow[t]{2}{*}{$\begin{array}{l}\text { Total } \\
\text { No of } \\
\text { centers }\end{array}$} & \multirow[t]{2}{*}{$\begin{array}{l}\text { Mean } \pm \text { SD } \\
\text { of complete } \\
\text { centers }\end{array}$} & \multicolumn{2}{|c|}{$\begin{array}{l}\text { No of } \\
\text { complete } \\
\text { centers }\end{array}$} & \multicolumn{2}{|c|}{$\begin{array}{l}\text { No of } \\
\text { incomplete } \\
\text { centers }\end{array}$} & \multicolumn{2}{|c|}{$\begin{array}{l}\text { No of } \\
\text { absent } \\
\text { centers }\end{array}$} \\
\hline & & & & No & $\%$ & No & $\%$ & No & $\%$ \\
\hline $\begin{array}{l}\text { GI } \\
\text { (control) }\end{array}$ & 68 & 204 & $3.00 \pm 0.0$ & 204 & 100.0 & 0 & 0.0 & 0 & 0.0 \\
\hline G IIa & 61 & 183 & $2.53 \pm 0.5^{* * *}$ & 154 & 84.2 & 29 & 15.8 & 0 & 0.0 \\
\hline G IIb & 0 & 180 & $1.31 \pm 0.5^{* * * *}$ & 7 & 43.9 & 68 & 37.8 & 33 & 18.3 \\
\hline G IIIa & 47 & 141 & $3.00 \pm 0.0^{8 * * *}$ & 141 & 100.0 & 0 & 0.0 & 0 & 0.0 \\
\hline G IIIb & 37 & 111 & $\underset{\$}{2 * * * * *} \pm 0.5^{* * * *}$ & 93 & 83.8 & 0 & 0.0 & 18 & 16.2 \\
\hline
\end{tabular}

Results are shown as: mean \pm SD of each group. No: Number

$\%$ : The percentage calculated from number of incomplete centers / total number of centers X 100

* Comparison control versus each treated group.

-§ Comparison between carbamazepine versus lamotrigine in both doses 


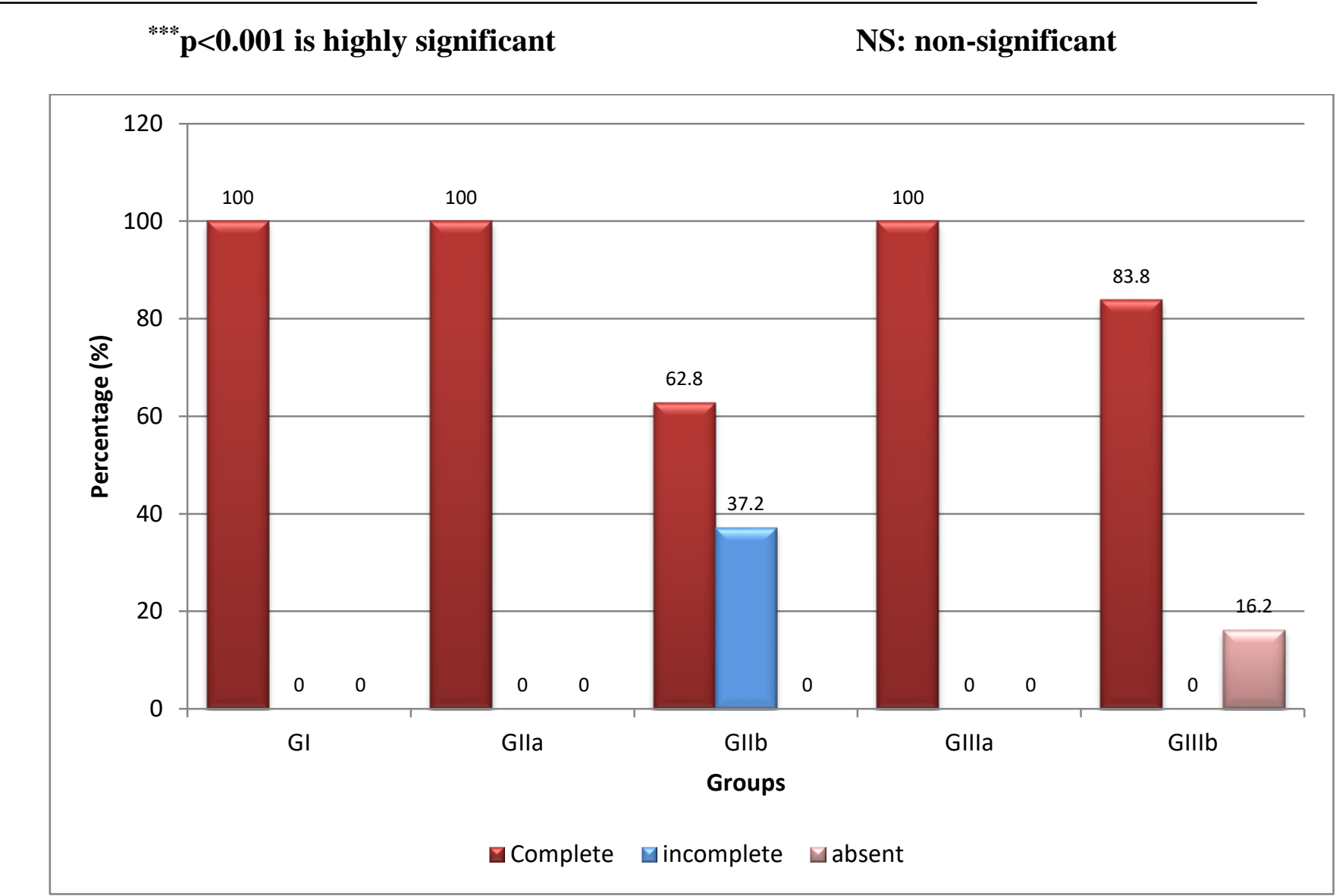

Figure (7): Effect of maternal AEDs administration on metacarpal Ossification centers of albino rat fetuses.

Metatarsal centers:

Table (8): Effect of maternal AEDs administration of metatarsal ossification centers of albino rat fetuses (Mt 1-3)

\begin{tabular}{|l|l|l|l|l|l|l|l|l|l|}
\hline \multirow{2}{*}{ Groups } & \multirow{2}{*}{$\begin{array}{l}\text { No. of } \\
\text { Fetuses }\end{array}$} & $\begin{array}{l}\text { Total } \\
\text { No of } \\
\text { centers }\end{array}$ & & $\begin{array}{l}\text { Mean } \pm \text { SD of } \\
\text { complete } \\
\text { centers }\end{array}$ & $\begin{array}{l}\text { No } \\
\text { complete } \\
\text { centers }\end{array}$ & \multicolumn{2}{|l|l|l|l|l|}{$\begin{array}{l}\text { No of } \\
\text { incomplete } \\
\text { centers }\end{array}$} & $\begin{array}{l}\text { No of } \\
\text { absent } \\
\text { centers }\end{array}$ \\
\hline GI (control) & 68 & 204 & $3.00 \pm 0.0$ & 204 & 100.0 & 0 & 0.0 & 0 & 0.0 \\
\hline G IIa & 61 & 183 & $3.00 \pm 0.0$ & 183 & 100.0 & 0 & 0.0 & 0 & 0.0 \\
\hline G IIb & 60 & 180 & $1.62 \pm 0.5^{* * *}$ & 98 & 54.4 & 82 & 45.6 & 0 & 0.0 \\
\hline G IIIa & 47 & 141 & $3.00 \pm 0.0^{\S N S}$ & 141 & 100.0 & 0 & 0.0 & 0 & 0.0 \\
\hline G IIIb & 37 & 111 & $\begin{array}{l}2.50 \pm 0.5^{* * *} \\
\S^{* * * *}\end{array}$ & 93 & 83.8 & 0 & 0.0 & 18 & 16.2 \\
\hline
\end{tabular}

Results are shown as: mean \pm SD of each group. $\quad$ No: Number

$\%:$ The percentage calculated from number of incomplete centers / total number of centers X 100

* Comparison control versus each treated group.

- Comparison between carbamazepine versus lamotrigine in both doses ${ }^{* * * *} \mathbf{p}<0.001$ is highly significant NS: non-significant 


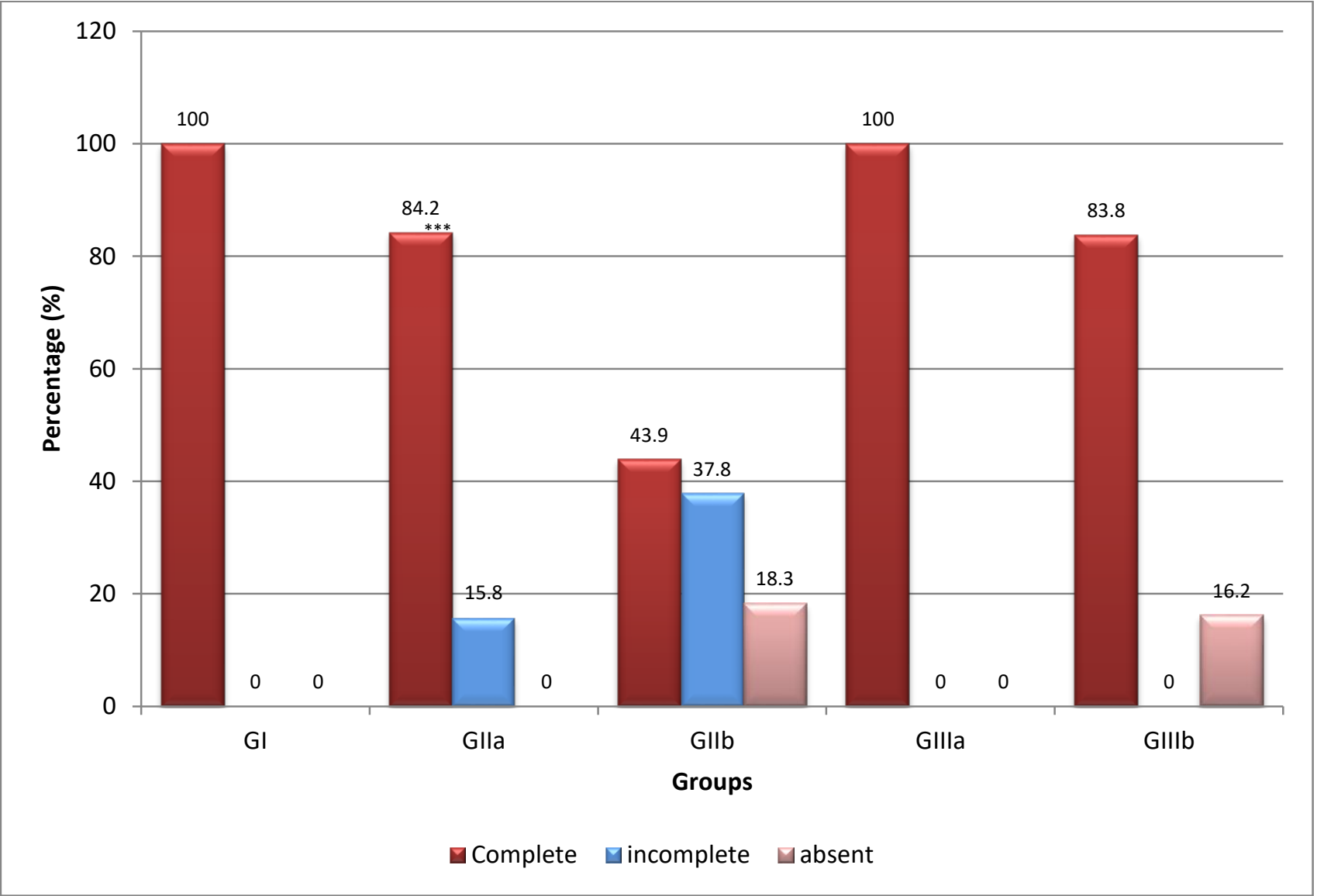

Figure (8): Effect of maternal AEDs administration on metatarsal ossification centers of albino rat fetuses

\section{PHOTOS:}

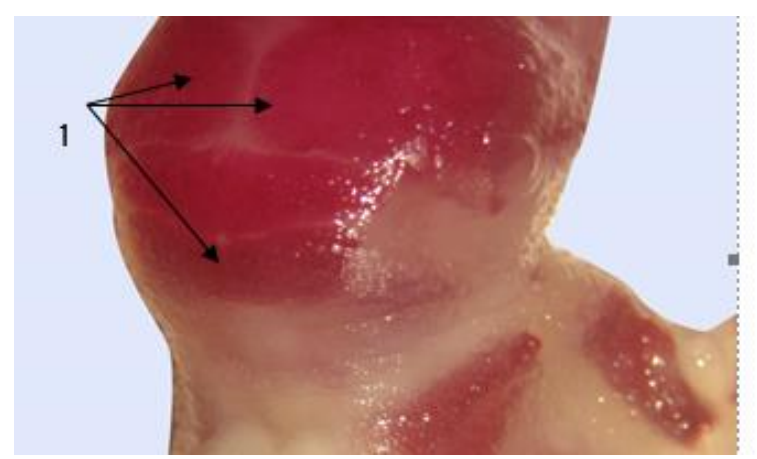

Photo. (1): Dorsal oblique view of fetus in group II a (therapeutic dose carbamazepine) (Alizarin specimen), showing:

1) Mild delayed ossification of parietal bone with inter-parietal fissuring (Alizarin stain X10)

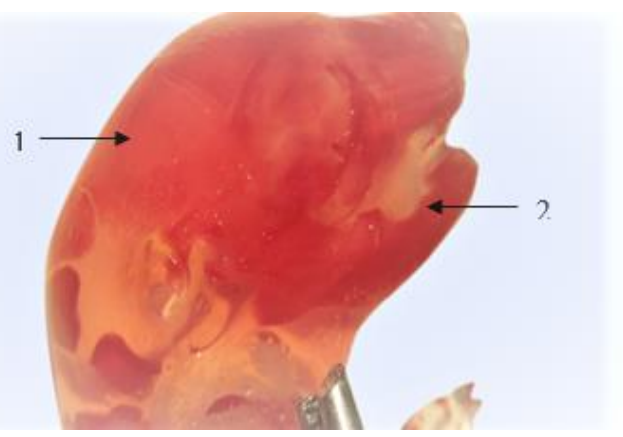

Photo. (2): Lateral view of fetus in group II a Photo. (3): Lateral view of fetus in group IIa (therapeutic dose carbamazepine) showing (numbers not accurately in place): -Marked ossification delay of:

1) Parietal and interparietal bones.

2) Exocciptal bone.

3) Lacrimal.

4) Maxilla.

5) Mandible.

6) Metacarpal bones. (Alizarin stain X10) 

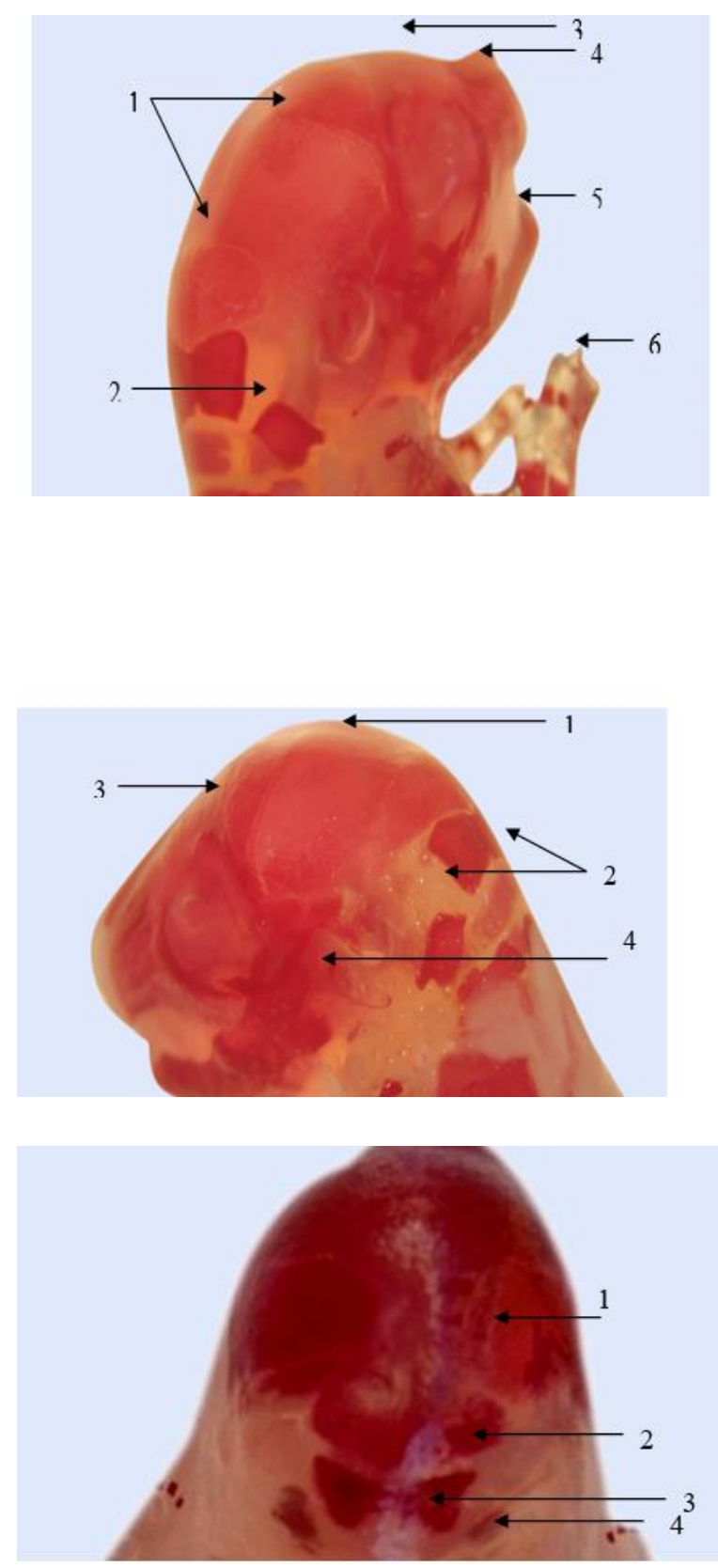

Photo. (4): Lateral view of fetus in group IIa (therapeutic dose carbamazepine), (Alizarin specimen), showing:

-Delayed ossification of:

1) Parietal and interparietal.

2) Supraoccipit and exoccipit.

3) Lacrimal bone.

4) Posterior aspect of mandible.

(AlizarinstainX10)

Photo. (5): Dorsal view of fetus in group IIb (1/4 $\mathrm{LD}_{50}$ carbamazepine) showing:

1) Mild delay in ossification of parietal bones with irregular rarified margin and persistent narrow inter parietal fissure.

-Moderate delay in ossification of:

2) Interparietal.

3) Supra exoccipit.

4) Exoccipit bones.

(Alizarin stainX10)

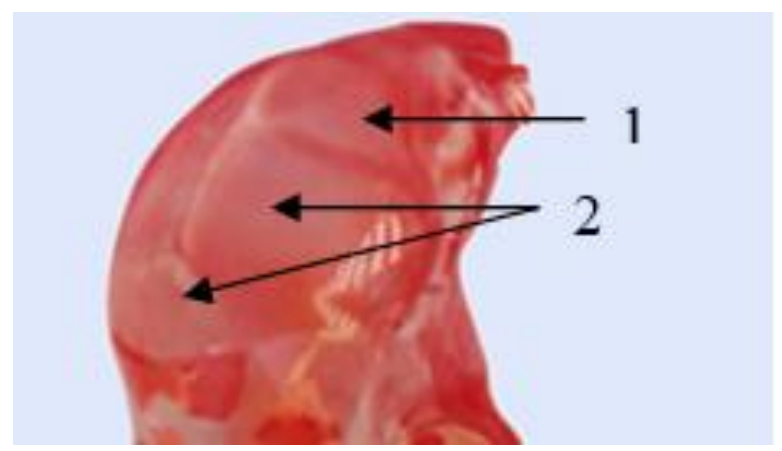

Photo. (6): Dorsal-oblique view of fetus in group IIb ( $1 / 4 L_{50}$ carbamazepine) showing marked delay in ossification of:

1) Frontal bones.

2) Parietal and inter parietal bones.

(Alizarin stainX10)

Photo. (7): Dorsal view of fetus in group II b ( $1 / 4 \mathrm{LD}_{50}$ carbamazepine) showing:

1) Defect of the right parietal bone with mild ossification delay in interpareital bones.

Mild delay in ossification of:

2) Supraoxccipit.

3) Exoccipit.

(Alizarin stainX10) 

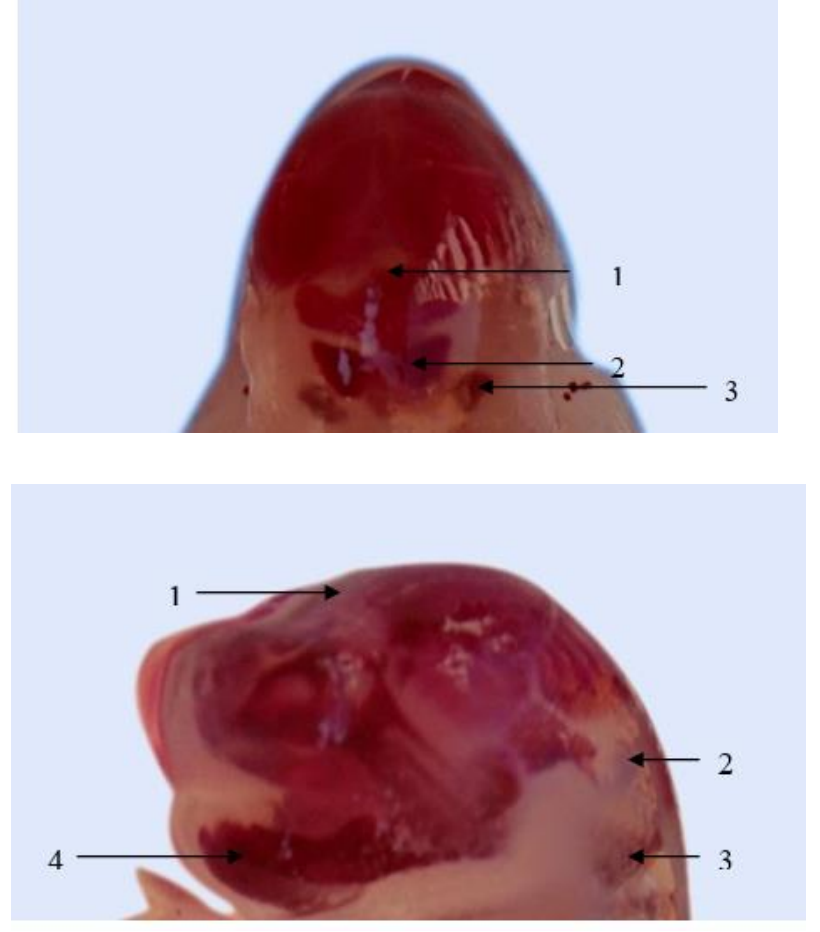

Photo. (8): Lateral view of fetus in group IIb ( $1 / 4 \quad \mathrm{LD}_{50}$ carbamazepine) showing marked ossification delay in:

1) Frontal bones.

2) Suproccipit.

3) Exoccipit.

4) Mandible (microganthia).

(Alizarin stainX10)

Photo. (9): Lateral view of fetus in group III a ( $1 / 4 \quad \mathrm{LD}_{50}$ Lamotrigine) showing:

1) Mild delayed ossification of maxilla.

2) Delayed ossification of posterior part of parietal bones

(Alizarin stainX10)

Photo. (10): Dorsal view of fetus in group III a ( $1 / 4 \quad$ LD $_{50}$ Lamotrigine) showing:

1) Interparietal fissure.

2) Severe ossification delay of exoccipit bones.

(AlizarinstainX10) 


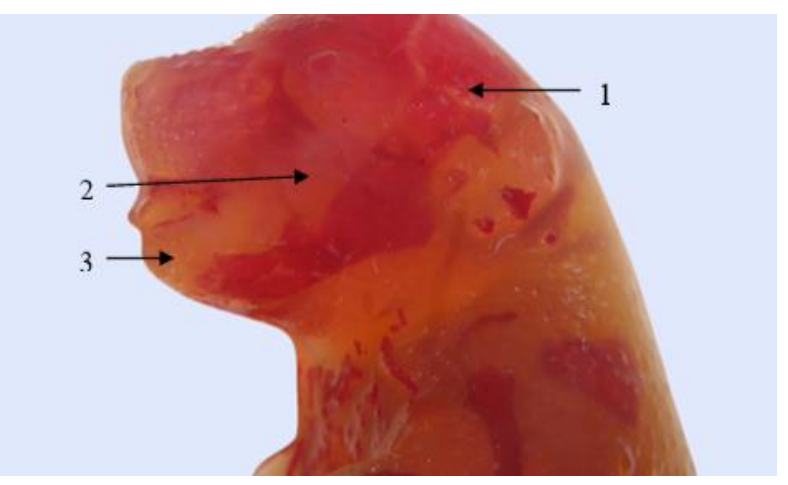

Photo. (11): Lateral view of fetus in group III b $\left(1 / 4 L_{50}\right.$ Lamotrigine) showing delayed ossification of:

1) lateral aspect of parietal bone.

2) Maxilla.

3) Body of mandible.

(Alizarin Stain X10)

Photo. (12): Lateral view of fetus in group III b ( $1 / 4 \quad$ LD $_{50}$ Lamotrigine $)$ showing delayed ossification of:

1) Posterior aspect of parietal bone.

2) Maxilla.

3) Lacrimal bone.

4) Tympanic bulla.

(Alizarin stain X10)

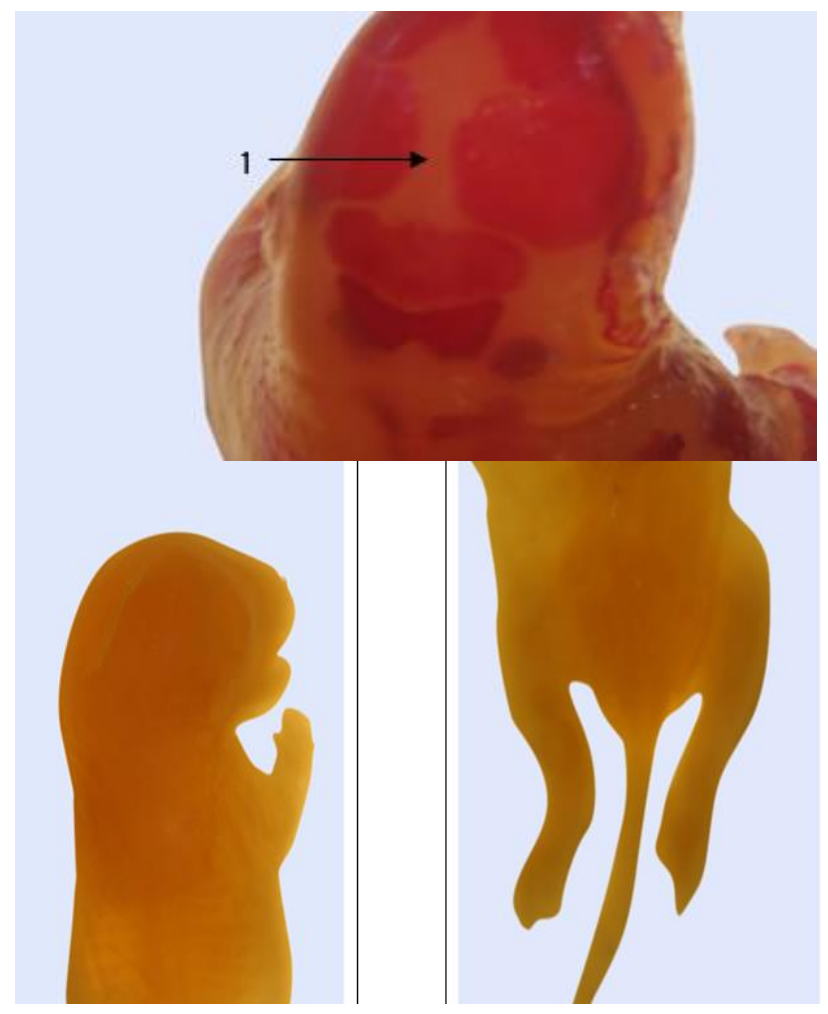

Photo. (13): Dorsal view of fetus in group III b ( $1 / 4 \mathrm{LD}_{50}$ Lamotrigine) showing: 1) Widening of interparietal fissure. (Alizarin stain X10)

Photo. (14): Dorsal-oblique view of fetus in group III b $\left(1 / 4 L_{50}\right.$ Lamotrigine) showing:

-Complete absence of ossification centers.

(Alizarin stain X10) 


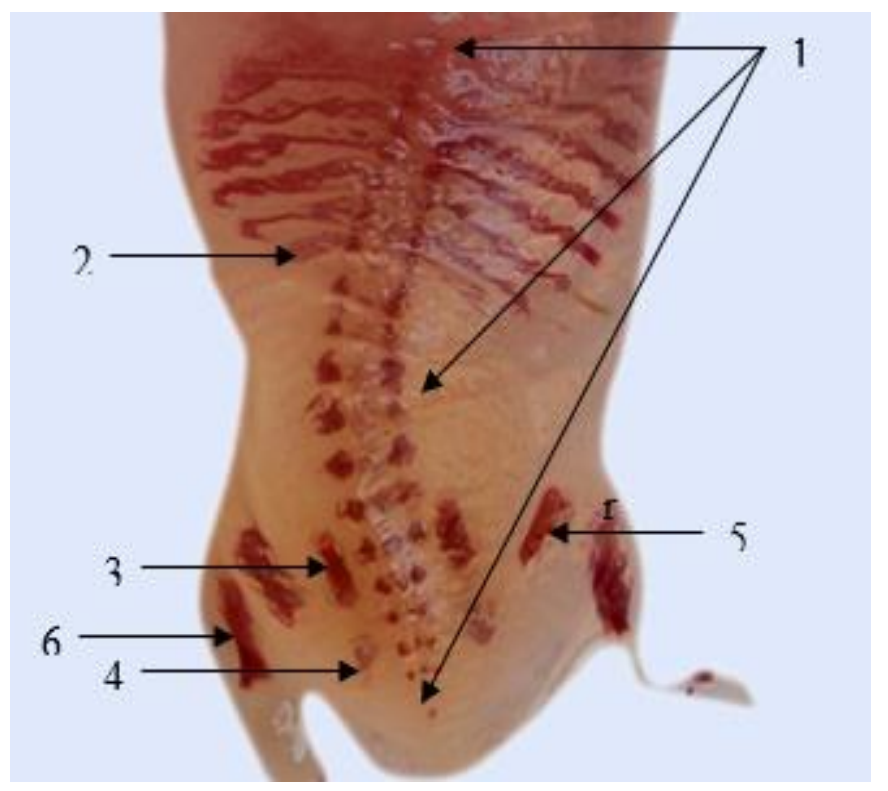

Photo. (15): Dorsal view of fetus in group IIb $\left(1 / 4 \mathrm{LD}_{50}\right.$ carbamazepine) showing:

1) Marked ossification delay in both vertebral bodies and arches down to the caudal vertebrae with scoliosis.

2) Moderate ossification delay in all ribs.

-Moderate ossification delay in:

3) ilium.

4) Ischium.

5) Femur.

6) Tibia.

(Alizarin stainX10)

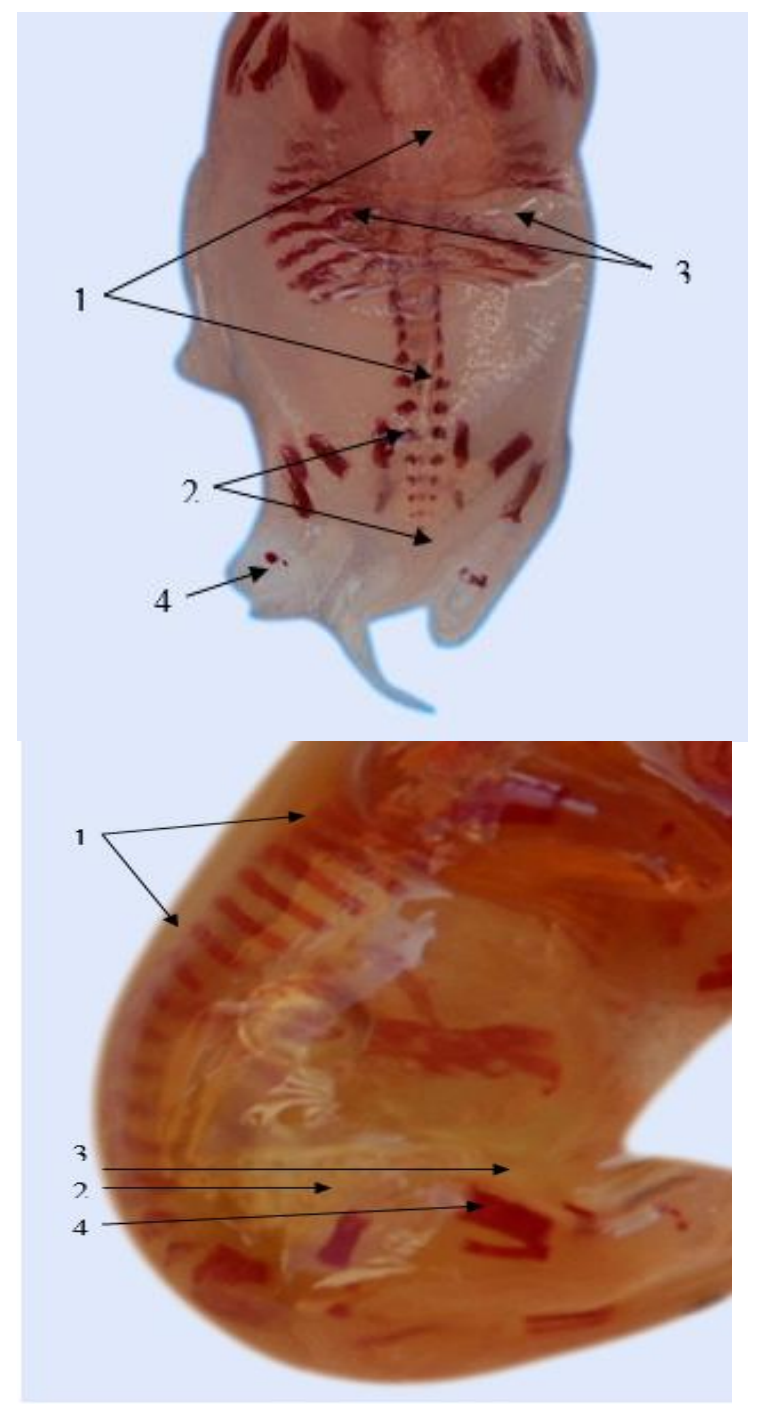

Photo. (16): Dorsal view of fetus in group IIb ( $\left(1 / 4 \quad \mathrm{LD}_{50}\right.$ carbamazepine $)$ showing:

1) Smaller centers of ossification in thoracic and lumbar region.

2) Tiny ossification centers in sacral and caudal vertebral arches.

3) Moderate ossification delay in the ribs with angulation of the left $10^{\text {th }}$ and wide space between right $10^{\text {th }}$ and $11^{\text {th }}$ rib.

4) Tiny ossification centers of metatarsal bones.

(AlizarinstainX10)

Photo. (17): Lateral view of fetus in group IIb ( $1 / 4 \mathrm{LD}_{50}$ carbamazepine $)$ showing:

1) Shortened ribs.

-Delayed development of leg bones in form of shortening:
2) Femur.
3) Tibia.
4) Fibula.

(Alizarin stain X10) 


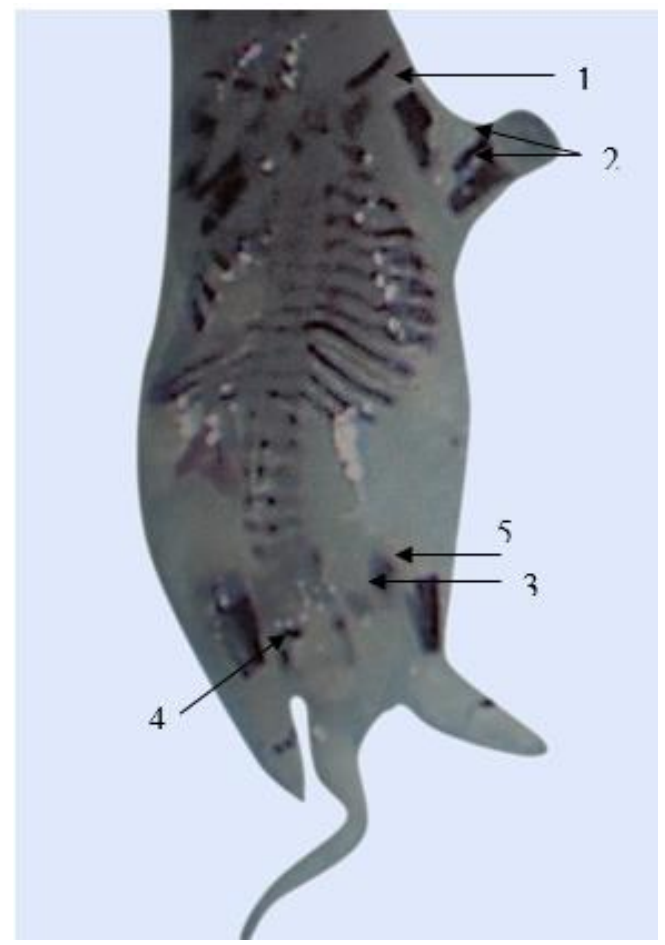

Photo. (18): Ventral-Oblique view of fetus in group II b $\left(\begin{array}{llll}1 / 4 & \mathrm{LD}_{50}\end{array}\right.$ carbamazepine) showing:

- Delayed ossification in vertebral bodies and arches.

- Moderate ossification delayed in:

1) Humerus.

2) Radius and ulna.

-Severe ossification delayed in:

3) Ilium.

4) Ischium.

5) Femur.

(Alizarin stainX10) 


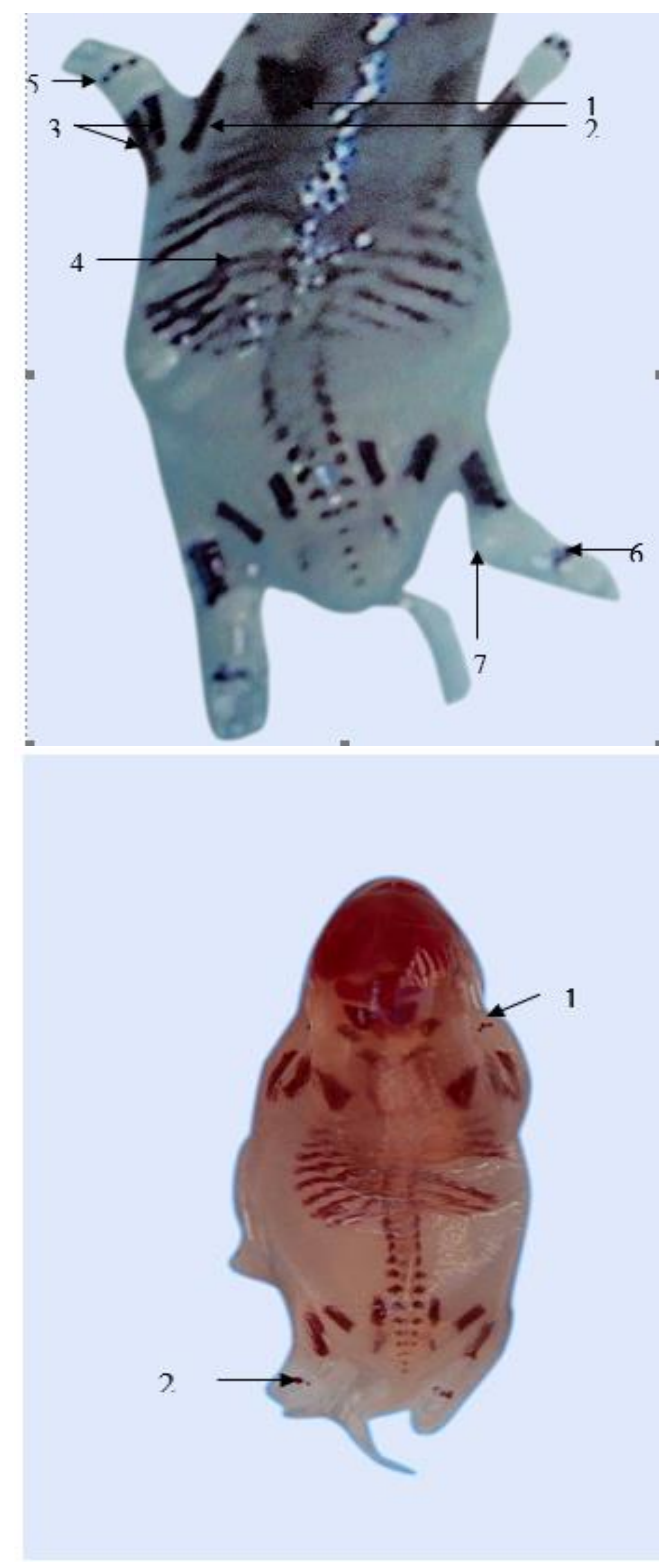

Photo. (19): Dorsal view of fetus in group IIb ( $1 / 4 \mathrm{LD}_{50}$ carbamazepine) showing: -Moderate delayed ossification in:

1) Scapula

2) Humurs.

3) Radius and ulna.

4) Angulation of ribs with wide space.

- Severe ossification delay in:

5) Metacarpal.

6) Metatarsal.

7) Absence calcaneus.

(Alizarin stainX10)

Photo. (20): Dorsal view of fetus in group II $b \quad\left(\begin{array}{lll}1 / 4 & L_{50} & \text { carbamazepine })\end{array}\right.$ showing:

1) Delayed ossification in metacarpal bone.

2) Tiny ossification centers of metatarsal bones.

(Alizarin stainX10) 


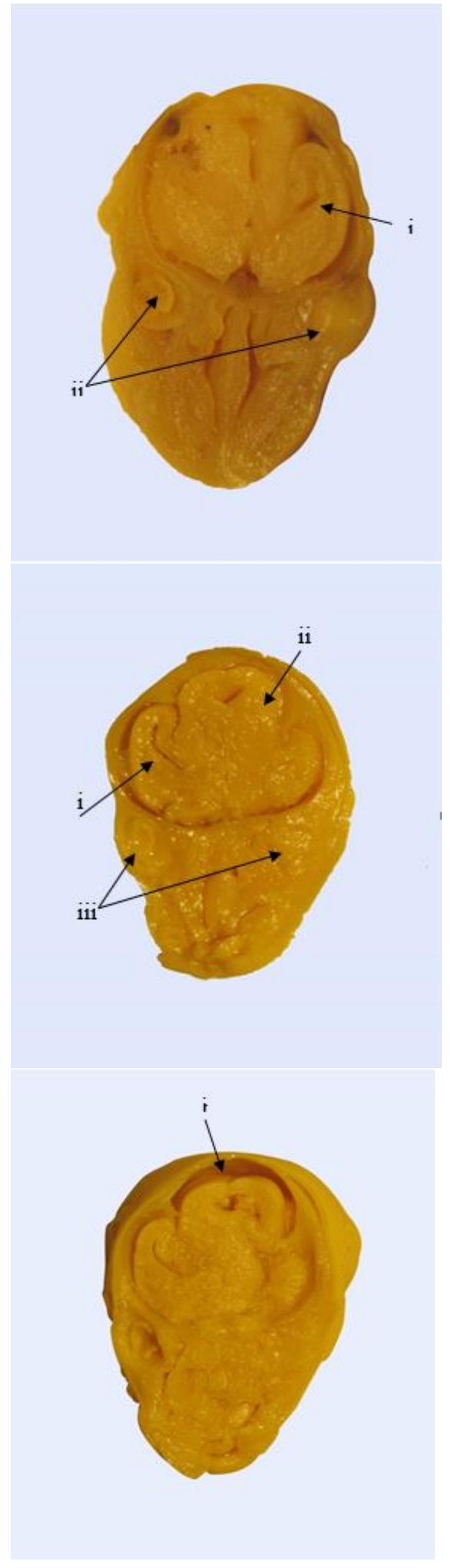

Photo. (21): Transverse section in the head of group II $b$ fetus ( $1 / 4 \mathrm{LD}_{50}$ carbamazepine) showing:

i) mild dilatation of the lateral ventricle and ii) delayed development of both eyes.

(Bouin's solution X10)

Photo. (22): Transverse section in the head of group II a fetus $\left(\begin{array}{lll}1 / 4 & L_{50}\end{array}\right.$ carbamazepine) showing:

i) dilatation of the lateral ventricle and ii) degenerative change of posterior aspect of brain

iii) delayed development of both eyes.

(Bouin's solution X10)

Photo. (23): Transverse section in the head of group II $b$ fetus $\left(1 / 4 \mathrm{LD}_{50}\right.$ carbamazepine) showing:

i) shrinkage of the brain.

(Bouin's solution X10) 


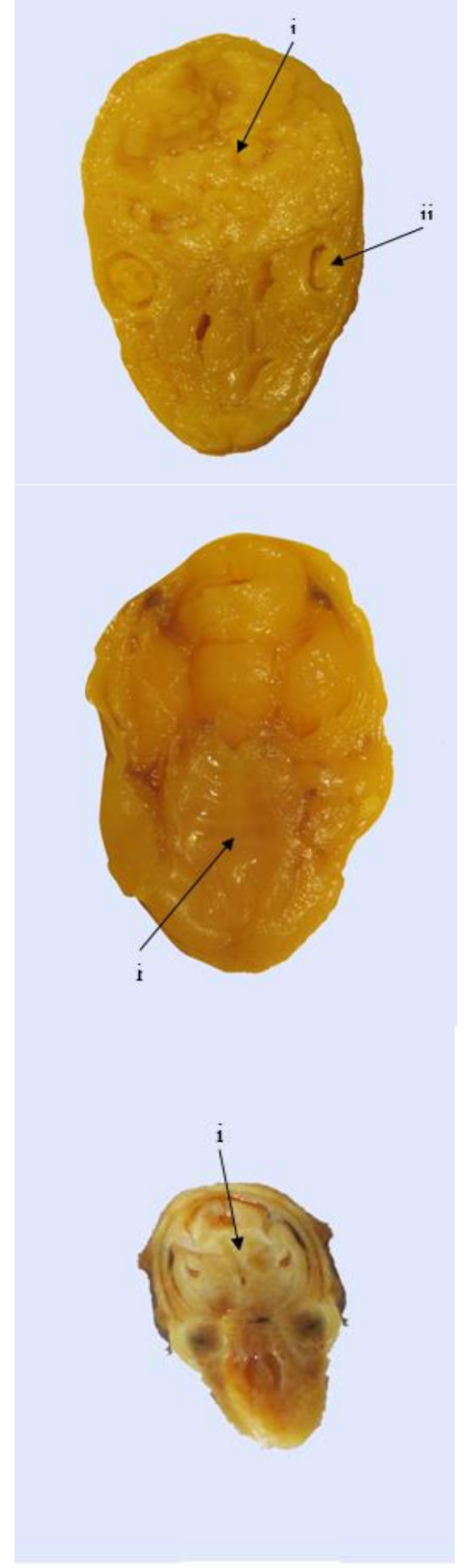

Photo. (24): Transverse section in the head of group II $b$ fetus $(1 / 4$

LD 50 carbamazepine) showing:

i) degenerative change of brain,

ii) delayed development of left eye.

(Bouin's solution X10)

Photo. (25): Transverse section in the head of group II $b$ fetus $\left(1 / 4 \mathrm{LD}_{50}\right.$ carbamazepine) showing:

i) moderate smoothness of upper palate.

(Bouin's solution X10)

Photo. (26): Transverse section in the head of group III $b$ fetus $\left(1 / 4 L_{50}\right.$ lamotrigine) showing:

i) degeneration of brain.

(Bouin's solution X10) 


\section{DISCUSSION}

The teratogenic effects of antiepileptic drugs (AEDs) were noticed 40 years ago when an association between their use and an increased risk of birth defects was observed (Tomson and Battino, 2008). Estimates were reported that exposure to AEDs raised the risk of malformation 2-3 folds (Speidel and Meadow, 1972) which was confirmed in human and animal studies (Gaily and Granstrom, 1992; Fisher et al., 2005). The risk increases with higher dosages, higher serum levels and/or polytherapy. Exposure to AED monotherapy leads to $4.5 \%$ major malformations in children while the exposure to polytherapy leads to $8.6 \%$ (Holmes et al., 2001).

Potential teratogenic effects are a major concern for all pregnant females with epilepsy. Unlike other medications, AEDs cannot be withdrawn, since uncontrolled seizures may be harmful to both the mother as well as the fetus. Risks associated with uncontrolled seizures have to be balanced against their teratogenic risk (Tomson and Battino, 2008). For this reason, the possible teratogenic effects of AEDs were studied in this research by comparing carbamazepine (old generation) with lamotrigine (new generation) in a trial to detect the AED that can be used safely by epileptic pregnant females.

Mechanisms proposed for AEDs teratogenicity included folate-related actions, ischemia, neuronal suppression, reactive intermediates (free radicals), and AED-induced neuronal apoptosis. All of these mechanisms remain hypothetical (Meador, 2008).

\section{SKELETAL FINDINGS}

Aliverti et al. (1979) and Ariyuki et al. (1982) established a relationship between low body weight and retarded ossification induced by teratogenic agents. They found that the stage of skeletal ossification in rat fetuses provided a reliable quantitative index for evaluating retarded fetal development in addition to conventional somatometric measurements such as body weight and crown-rump length.

All AEDs used in the present study clearly affected the fetal skeletons of AED-treated mother rats. Findings detected were as follows:

Craniofacial centers:

Fetal OCs showed a highly significant decrease in ossification in all groups as compared to the control. By comparing the therapeutic dose of both drugs, no significant increase in the mean of complete OCs was observed; While by comparing the $1 / 4 \mathrm{LD}_{50}$ of both drugs, lamotrigine showed a high significant decrease in the mean of complete OCs as compared to carbamazepine. In the fetuses of the group treated by $1 / 4 \mathrm{LD}_{50}$ of lamotrigine, the parietal bones were the most affected bone in the craniofacial region, showed widening of interparietal fissure.

The current findings agreed with Padmanabhan et al. (2003) who reported skeletal findings in fetal skulls in the experimental group exposed to lamotrigine, where skulls were smaller in size as compared to controls, their vaults were poorly ossified; the maxillae were split laterally. Maxillary 
and mandibular hypoplasia were invariably present.

- Vertebral centers:

By comparing the 2 drugs (therapeutic dose) and the control, fetal OCs in different regions of the vertebral column showed no significant change in the mean of complete OCs. Therefore, all AEDs (old and new generations) in the therapeutic dose are considered safe as regards their effect on the vertebral centers. These results are in agreement with Gerenutti et al. (2008) who found no delay in the ossification of vertebral centers in a study of the possible effects of carbamazepine in pregnant female rats.

By comparing the 2 drugs $\left(1 / 4 \mathrm{LD}_{50}\right)$, a highly significant decrease in the mean of complete OCs was recorded. The current findings agreed with Soysal et al.(2011), in their study conducted on albino rats to study the skeletal effects of phenytoin, noted that the intensity of the ossification gradually decreased from the mid thoracic vertebrae through caudal direction (completely cartilaginous), with no ossification in lumbar and sacral vertebrae.

Phenytoin and carbamazepine have been associated with patterns of malformation that are quite similar. The mechanism by which carbamazepine exerts its teratogenicity is largely unknown, but the study on mice indicated that it could be bio transformed to a reactive teratogenic metabolite that might be responsible for the observed fetotoxicity (Hanson and Smith, 1975; Jones et al., 1989; Finnell et al., 1995).

The current findings in carbamazepine $1 / 4 \mathrm{LD}_{50}$ treated group regarding the vertebral column which showed very highly significant delayed in ossification agreed with Soysalet al.(2011), in their study conducted on albino rats to study the skeletal effects of phenytoin, noted that the intensity of the ossification gradually decreased from the mid thoracic vertebrae through caudal direction (completely cartilaginous), with no ossification in lumbar and sacral vertebrae.

- The sternum:

All treated groups showed complete ossification of all sternebrae, except in lamotrigine $\left(1 / 4 \quad \mathrm{LD}_{50}=32 \mathrm{mg} / \mathrm{kg}\right)$ treated group which showed $16.2 \%$ complete absence of ossification centers. This agreed with

Padmanabhan et al. (2003) in their studies on the reproductive toxicologic effects of lamotrigine in mice that reported that most sternal anomalies were found to have occurred in single high dose $(50,100$ and $200 \mathrm{mg} / \mathrm{kg}$ ) and triple dose $(25,50$, and $75 \mathrm{mg} / \mathrm{kg}$ of lamotrigine were administered at 3 hour intervals), these anomalies were hypoplasia, agenesis and malpositioning of sternebrae, non-union of the bilateral halves of sternebrae and supernumerary sternebrae.

- The ribs:

All treated groups showed complete ossification of all ribs, except in carbamazepine $\left(1 / 4 \mathrm{LD}_{50}=97 \mathrm{mg} / \mathrm{kg}\right)$, which showed $13.3 \%$ incomplete ossification, $10 \%$ angulation and $6.7 \%$ short ribs; while in lamotrigine $(1 / 4$ $\mathrm{LD}_{50}$ ) of $16.2 \%$ showed complete absence of OCs. On the contrary, Gerenutti et al. (2008) and Afshar et al. (2011) did not mentioned any ribs anomalies in their experimental studies on carbamazepine at doses of (20 and $40 \mathrm{mg} / \mathrm{kg}$ in rats) and (30 and $60 \mathrm{mg} / \mathrm{kg}$ in mice) respectively. These results are in agreement with Padmanabhan et 
al.(2003) and Soysal et al.(2011) who reported the presence of rib anomalies in high doses of AEDs.

The Appendicular Skeleton:

- The clavicle:

All treated groups showed complete ossification of clavicles, except in lamotrigine $\left(1 / 4 D_{50}\right)$ which showed $16.2 \%$ complete absence of ossification.

- The scapula and forelimbs (humerus, radius and ulna):

They were completely ossified in the groups treated with the therapeutic dose except in the groups treated with the $1 / 4 \mathrm{LD}_{50}$ dose where carbamazepine showed delayed ossification while lamotrigine showed complete absence of OCs. Soysal et al. (2011) agreed with the present finding, he reported that the phenytoin can cause ossification delay in humerus, radius and ulna. Available literature showed no findings concerning both the clavicle and the scapula.

- Metacarpal OCs:

Fetal OCs showed highly significant decrease in the mean of complete ossification centers in carbamazepine (therapeutic dose and $1 / 4$ $\left.\mathrm{LD}_{50}\right)$ and lamotrigine $\left(\begin{array}{lll}1 / 4 & \left.\mathrm{LD}_{50}\right) & \text { in }\end{array}\right.$ comparison with the control. Lamotrigine (therapeutic dose and $1 / 4$ $\mathrm{LD}_{50}$ ) showed highly significant increase in the mean of complete OCs in comparison with the corresponding doses of carbamazepine treated group.

As observed carbamazepine has an adverse effect, while lamotrigine in therapeutic dose is the best drug regarding metacarpal bone ossification. This agreed with Soysal et al. (2011), who reported slight metatarsal bone ossification and no phalangeal ossification in the effect of phenytoin on the fetal skeleton. Hanson et al. (1976), described the fetal hydantion syndrome which is characterized by facial anomalies in association with digital hypoplasia, it was described in infants exposed to phenytoin and carbamazepine. Delgado-Escueta and Janz (1992) showed that the exposure to other anticonvulsants resulted in the same picture (anticonvulsant syndrome) and it was 2-7 folds the normal population. These results also agreed with Jones et al. (1989) and Ornoy and Cohen (1996) who stated that distal digital hypoplasia occurred in carbamazepine exposed children compared to controls together with Holmes et al. (2005) who reported that children exposed to anticonvulsants (phenytoin, phenobarbital, and carbamazepine as mon and polytherapy) during pregnancy have an increased frequency of midface and digital hypoplasia.

- Hindlimbs:

Ossification of ileum, ischium, femur, tibia and fibula were only affected in $1 / 4 \mathrm{LD}_{50}$ of carbamazepine and lamotrigine (incomplete or absent OCs respectively) which was similar to the findings of Soysal et al. (2011) on fetal femurs and fibulas exposed to phenytoin.

- Metatarsal OCs:

The fetal metatarsal bone OCs showed no abnormalities in therapeutic doses of both drugs. On the other hand, a highly significant decrease in the mean of complete OCs was detected in the $1 / 4 \quad L_{50}$ of both drugs. So, therapeutic doses are considered safe regarding their effect.

Gerenutti et al. (2008) and Afshar et al., (2011) mentioned no defects in metatarsal bones. Carbamazepine was given in doses of 20 and $40 \mathrm{mg} / \mathrm{kg}$ in 
rats and 30 and $60 \mathrm{mg} / \mathrm{kg}$ in mice which agreed with the current results of carbamazepine therapeutic dose $(18 \mathrm{mg} / \mathrm{kg})$.

In a trial to interpret the occurrence of fetal skeletal defects in association with AEDs, LaRoche and Helmers (2004) reported that the antiepileptic drugs cause hypocalcemia, hypophosphatemia, reduced serum levels of biologically active vitamin-D metabolites, and elevated serum parathyroid hormone, but the mechanism of decreased bone mineral density in adults differs depending on the drug administered. Pack (2003), stated that drugs in the same class as carbamazepine (phenobarbital, phenytoin, primidone) cause induction of the hepatic cytochrome $\mathrm{P}_{450}$ enzyme, $\mathrm{CYP}_{3} \mathrm{~A}_{4}$ that leads to metabolism of calcitriol into in-active metabolites, which in turn leads to the decrease of bone mineralization, serum calcium, and bone-density. Reduced serum calcium stimulates a positive feedback from the parathyroid glands, upregulating the amount of parathyroidhormone secreted (secondary hyperparathyroidism).

VISCERAL ANOMALIES:

Normal findings were observed in all histological sections regarding the therapeutic dose of both drugs while in the $1 / 4 \quad L_{50}$ dose, findings were recorded only in sections at both drugs. Carbamazepine ( $1 / 4 \mathrm{LD}_{50}$ treated group), dilatation of the lateral ventricles of the brain was seen, this finding is in agreement with Sullivan and Mc Elhatton (1977), who reported that there was enlarged cerebral ventricles in fetal brains of mice treated with carbamazepine. In the current study, fetal rats showed smoothness of upper palates which agreed with Sullivan and
Mc Elhatton (1977) who reported that there were abnormal palatal bones other than cleft palate, and also with Rosa (1991) and Hernandez-Diaz et al. (2012) who found that in utero carbamazepine exposure was associated with an increased risk of oro-facial clefts. Hernandez-Diaz et al. (2012) reported a 24-fold increase of isolated oral clefts compared with the prevalence in the general population (frequency of 0.19 out of 1000).

Lamotrigine $\quad\left(1 / 4 \quad \mathrm{LD}_{50}\right.$ treated group), in the current study showed areas of softening and degeneration, Marchi et al. (2001) and Manentet al. (2008) reported the presence of brain anomalies, which agreed with the current results, although these types of anomalies were different from those recorded in this study.

In the current study $1 / 4$ LD50 of carbamazepine treated group showed smoothness of the upper palate, which is in agreement with Sullivan and Mc Elhatton (1977) who reported that there was abnormal palatal bones other than cleft palate, and also with Rosa (1991) and Hernandez-Diaz et al. (2012) who found that in utero carbamazepine exposure was associated with an increased risk of orofacial clefts. Hernandez-Diaz et al. (2012) reported a 24-fold increase of isolated oral clefts compared with the prevalence in the general population (frequency of 0.19 out of 1000).

\section{CONCLUSION}

Lamotrigine in therapeutic dose can be used safely by epileptic pregnant females regarding skeletal and visceral anomalies and are dose dependent. 


\section{RECOMMENDATIONS}

Risk reduction should be practiced since even healthy parents have 2-3\% risk of having a child with a malformation.

- Management of epileptic pregnant females presents unique challenges. Confirmation of the diagnosis and verification of the most appropriate AED are the starting points. With effective patient education and careful and consistent management (including coordinated treatment planning by both neurologist and obstetrician) these patients have successful pregnancies and healthy offspring.

- Monitoring free drug levels both before and during pregnancy permit accurate assessment of concentrations in a situation where plasma protein binding is in flux. Dose adjustment, should be made on a clinical basis.

- Keep the dose as low as possible during conception and organogenesis, and raise it during the third trimester to reduce risk of seizures during labor.

- Regular monitoring should be done, anatomic ultrasonography at early weeks to identify structural defects and maternal serum alpha fetoprotein.

- In general, risks can be minimized by the preconceptual use of multivitamins (including vitamin $\mathrm{B}_{6}$ ) with folic acid, AEDs in monotherapy at the lowest effective dose, and by preventing maternal seizures.

- $\quad$ Folic acid $(5 \mathrm{mg} /$ day) should be taken for three months prior to conception and during the first trimester to prevent folic acid deficiency induced malformations (i.e., neural tube defects).

- Performance of multicenter prospective and population-based studies of pregnancy outcome according to standardized study protocols and procedures.

- We recommended the use of AEDs (old or new generations) in the effective therapeutic dose to control epilepsy in pregnant females.

- New are better than old AEDs because they cause no major congenital malformation as neural tube defects.

\section{REFERENCES}

Afshar, M.; Moallem, S.A.; Mohammadpour, A.; Shiravi, A.; Jalalian, S. and Golalipour, M. (2011): Teratogenic effects of carbamazepine on embryonic eye development in pregnant mice. Cutan.Ocul.Toxicol., 29(1):10-15.

Aldenkamp, A.P.; De Krom, M. and Reijs R. (2003): Newer antiepileptic drugs and cognitive issues. Epilepsia. 44 (Suppl 4):219.

Aliverti, V.; Bonanomi, L.; Giavini, E.; Leone, V.G. and Mariani, L. (1979): The extent of the fetal ossification as an index of delayed development in teratogenic studies on the rat. Teratology, 20(2):23742.

Anon (2013 a): [online] Available at: https://www.caymanchem.com/msd ss/15422m.pdf [Accessed 26 Sep. 2013].

Anon (2013 b): [online] Available at: https://www.caymanchem.com/msd ss/15428m.pdf [Accessed 26 Sep. 2013].

Ariyuki, F.; Ishihara, H.; Higaki, K. and Yasuda, M. (1982): A study of fetal growth retardation in teratological tests: relationship between body weight and ossification of the skeleton in rat fetuses. Teratology, 26(3): 263-7.

Czapinski, P., Blaszczyk B. and 
Czuczwar S.J. (2005): Mechanism of action of antiepileptic drugs. Curr. Top. Med Chem., 5(1): 3-14.

Delgado-Escueta, A.V. and Janz, D. (1992): Consensus guidelines: preconception counseling, management, and care of the pregnant woman with epilepsy. Neurology, 42(4 Suppl 5):149- 60.

Drury, R. and Wallington, E. (1980): Carlton's Histological Technique. $5^{\text {th }}$ edition, Oxford University Press.

Farber; N.B, Jiang; XP, Heinkel C. and Nemmers B. (2002): Antiepileptic drugs and agents that inhibit voltage-gated sodium channels prevent NMDA antagonist neurotoxicity. Mol Psychiatry. 7(7):726-33.

Finnell, R.H.; Bennett, G.D.; Slattery, J.T.; Amore, B.M.; Bajpai, M. and Levy, R.H. (1995): Effect of treatment with phenobarbital and stiripentol on carbamazepine-induced

teratogenicity and reactive metabolite formation.

Teratology,52(6):324-32.

Fisher, R.S.; van Emde Boas; W., Blume, W., Elger, C., Genton, P., Lee, P. and Engel, J. (2005): Epileptic seizures and Epilepsy: definitions proposed by the International league Against Epilepsy (ILAE) and the International Bureau for Epilepsy (IBE). Epilepsia, 46(4):470-2.

Fritz H. and Hess R. (1970): Ossification of the rat and mouse skeleton in the prenatal period. Teratology, 3(4):331-8.

Gaily, E. and Granstrom, M.L. (1992): Minor anomalies in children of mothers with epilepsy. Neurology, 42 (4 Supp15):128-31.
Gerenutti, M.; Oliveira, C.C.; Miranda, A.C.R.; Rosa, R.M. and Sa Del Fiol, F. (2008): Reproductive performance and embryotoxicity of rats exposed to carbamazepine. (Revista Brasileira de

Cicncias

Foarmaceuticas,44(3):509- 14

Hanson, J.W.;

Myrianthopoulos, N.C.;

Harvey, M.A. and Smith, D.W. (1976): Risks to the offspring of women treated with hydantoin anticonvulsants, with emphasis on the fetal hydantoin syndrome. J. Pediatr., 89(4): 662-8.

Hanson, J.W. and Smith, D.W. (1975): The fetal hydantoin syndrome. J. Pediatr., 87(2): 25890.

Hernandez-Diaz, S.; Smith, C.R.; Shen, A.; Mittendorf, R.k; Hauser, W.A.; Yerby, M.; Holmes, $\quad$ L.B.; North American

AED Pregnancy Registry and North American ED Pregnancy Registry

(2012):Comparative safety of antiepileptic during pregnancy. Neurology, 78(21):1692-9

Holmes, L. B.; Harvey, E.; Coull, B.; Huntington, K.; Khoshbin, S.; Hayes, A. and Ryan, L. (2001): The teratogenicity of anticonvulsant drugs. N Engl J Med., 344(15):1132-8.

Holmes, L.B.; Coull, B.A.; Dorfman J. and Rosenberger; P.B.(2005): The correlation of deficits in IQ with midface and digit hypoplasia in children exposed in utero to anticonvulsant drugs. J. Pediatr., 146(1):118-22. .

Ibrahim, N.A. (2003): Effect of khat 
on intrauterine fetal growth and on the development of the fetal skeleton in albino rats. J. Anatomy, 26(1):57-84.

Jones, K.L.; Lacro, R.V.; Johnson, K.A. and Adams, J. (1989): Pattern of malformations in the children of women treated with carbamazepine during pregnancy. N. Engl. J. Med., 320 (25):1661-6.

Kimmel, C. A.; La Borde, J.B. and Trammell, C.T. (1982): Evaluation of cartilage and bone formation in fetal skeletons following prenatal insult reveal abnormalities not apparent in alizarin-stained specimens. Teratology, 25 (2):54A-55A.

Landmark, C. J. (2008): Antiepileptic drugs in non-epilepsy disorder: relation between mechanisms of action and clinical efficacy. CNS Drugs, 22(1):27-47.

La Roche, S.M. and Helmers, S.L. (2004): The new antiepileptic drugs: clinical applications. J.A.M.A., 291(5): 615-20.

Manent, J.B.; Jorquera, I.; Franco, V.; Ben-Ari, Y.; Perucca, E. and Represa, A. (2008): Antiepileptic drugs and brain maturation: Fetal exposure to lamotrigine generates cortical malformations in rats. Epilepsy Res., 78 (2-3):131- 9.

Marchi, N.S.; Azoubel, R. and Tognola, W.A. (2001): Teratogenic effects of lamotrigine on rat fetal brain: a morphometric study. Arq. Neuropsiquiatr., 59(2-B):362-4.

Meador, KJ. (2008): Effects of in utero antiepileptic drug exposure. Epilepsy Curr., 8(6):143-7.

Ornoy, A. and Cohen, E. (1996): Outcome of children born to epileptic mothers treated with carbamazepine during pregnancy.
Arch. Dis. Child,75 (6): 517-20.

Pack, A.M. (2003): The association between antiepeleptic drugs and bone disease. Epilepsy Curr., 3 (3): 91-5.

Padmanabhan, R., Abdulrazzaq, Y.M., Bastaki, S.M., Shafiulla, M. and Chandranath, S. (2003): Experimental studies on reproductive toxicologic effects of lamotrigine in mice. Birth Defects Res. B. Dev. Reprod. Toxicol., 68(5):428-38.

Paget, G.E. and Barnes, J. M. (1964): Toxicological tests in evaluation of drug activities. Edited by: Laurence D.R. Pharmacometrics. New York: Acad. Press, 13:134-5.

Perucca, E. (2005): An Introduction to antiepileptic drugs. Epilepsia, 46(4):31-7.

Porter, R.J. and Meldrum, B.S. (2004): Anti seizure drugs. In: Text book of basic and clinical pharmacology. Edited by: Kutzung B.G. $9^{\text {th }}$ edition. McGraw-Hill: Medical publishing division, ch.24:379-400.

Richmond, G. and Bennett, L. (1938): Clearing and staining of embryos for demonstrating ossification. Stain technology, 13:77- 9.

Rosa, F. (1991): Spina bifida in infants of women treated with carbamazepine during pregnancy, N. Engl. J. Med., 324 (10):674-7.

Soysal, H.; Unur, E.; Duzler, A.; Karaca, O. and Ekinci, N. (2011): Effects of intraperitoneal administration of the phenytoin on the skeletal system of rat fetus. Seizure, 20(3): 187- 93.

Speidel, B.D. and Meadow, S.R. (1972): Maternal epilepsy and abnormalities of the fetus and newborn. Lancet, 2(7782):839-43. 
Sullivan, F. M. and Mc Elhatton, P.R. (1977): A comparison of the teratogenic activity of the antiepileptic drugs carbamazepine, clonazepam, ethosuximide, phenobarbital, phenytoin, and primidone in mice. Toxicol. Appl. Pharmacol., 40(2): 365-78.

Tomson, T. and Battino, D. (2008): Teratogenic effects of antiepileptic drugs. Seizure, 17(2): 166- 71.

Walker, D.G. and Wirtschafter, Z.T. (1957): The Genesis of the rat skeleton. A laboratory Atlas. Charles C. Thomas. Publishers J. Anat., 168:314-321.

Wilson, J.G. (1964): Teratogenic interaction of chemical agents in the rat. J. Pharmacol. Exp. Ther., 144 (3): 429-36. 


\title{
التشوهات الخلقية المحتملة لأدويه الصرع في الفئران البيضاء

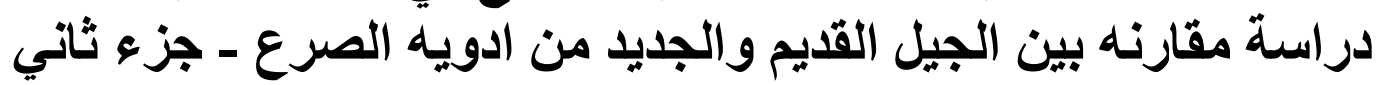

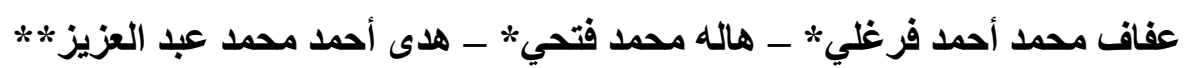

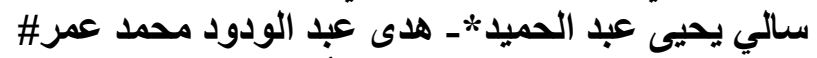

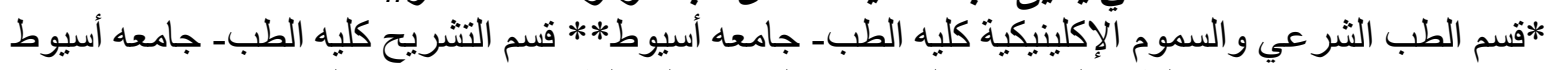

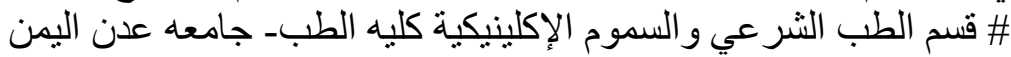

جميع الأدوية المضادة للصر ع إما معروفة أو يشتبه في كونها مسببات للتشوهات الخلقية. من المحتمل أن تكون التهاء

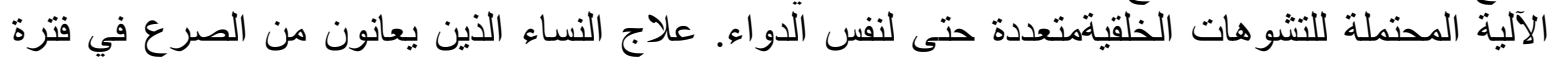

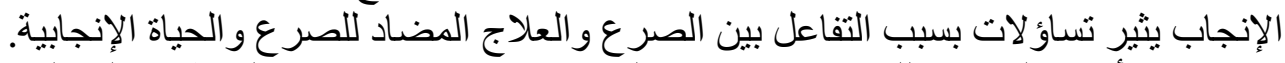

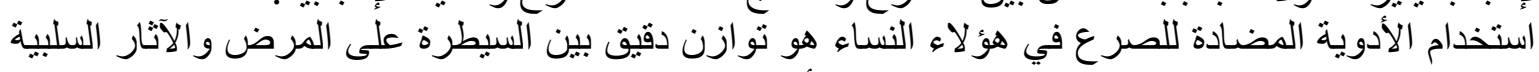

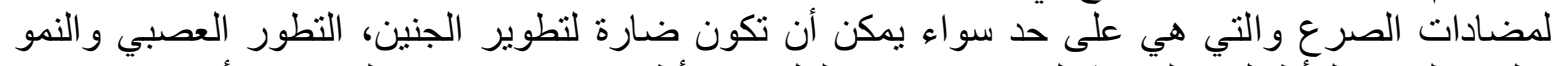

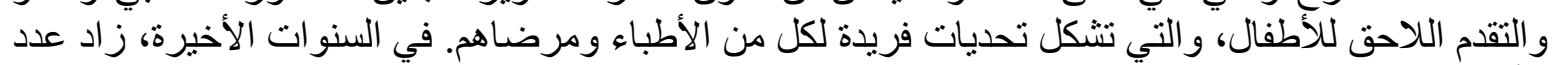

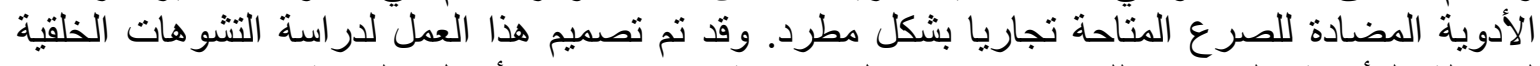

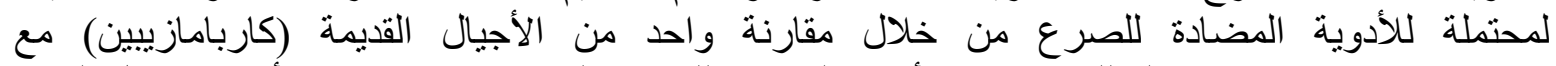

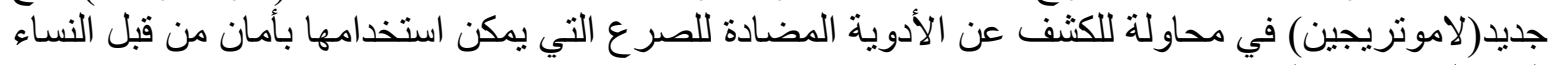

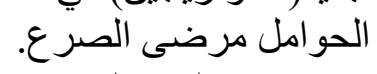

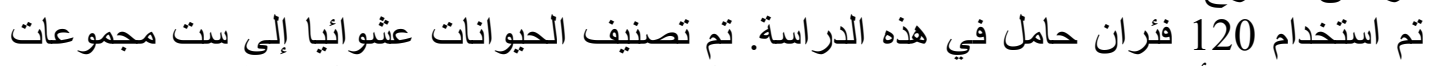

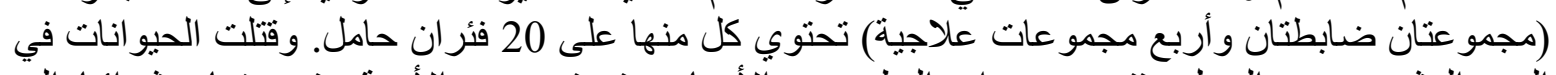

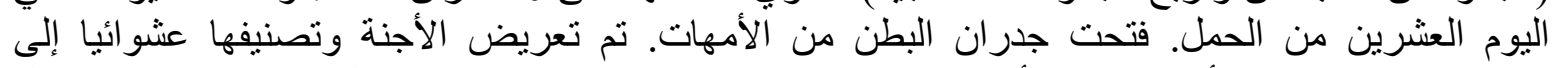

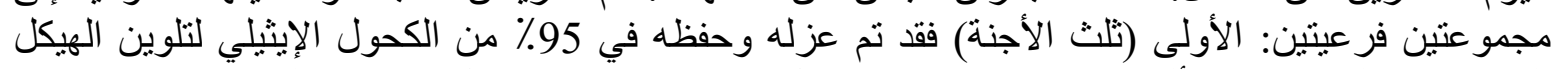

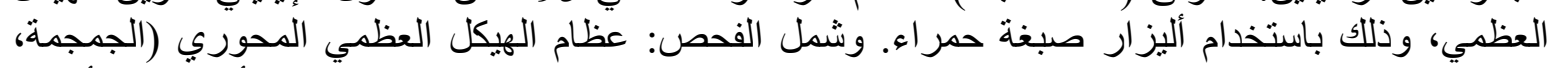

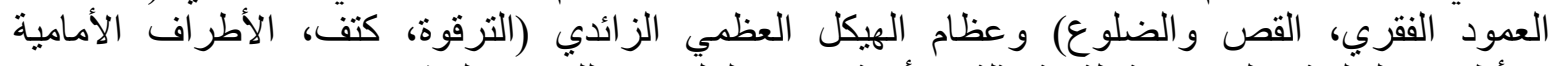

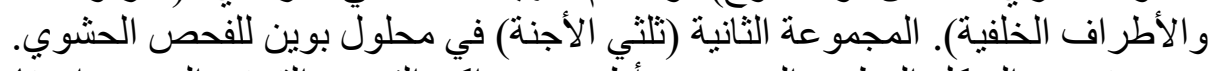

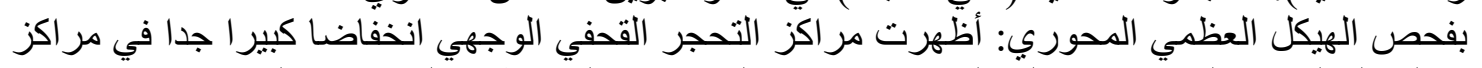

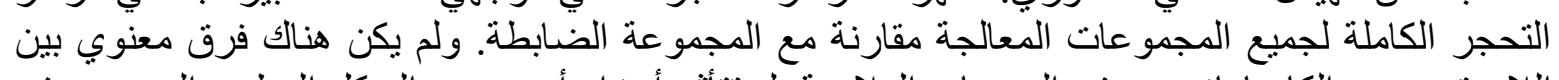

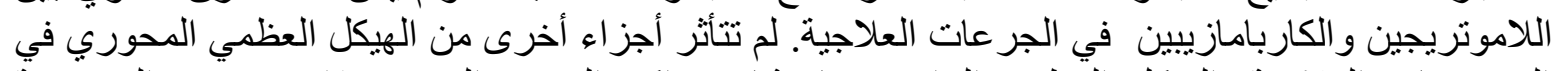

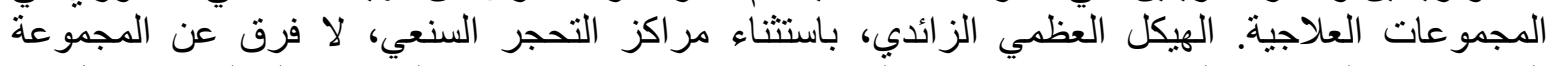

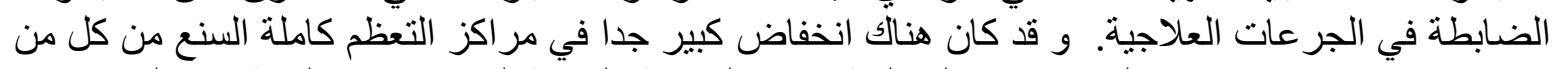

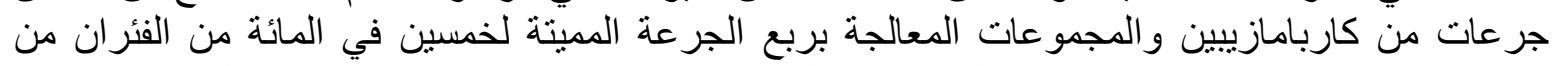

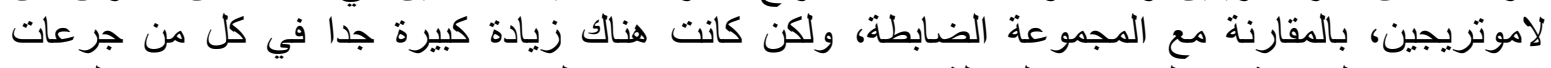

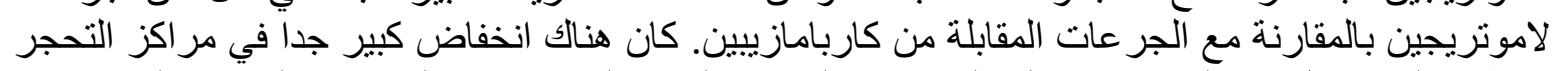

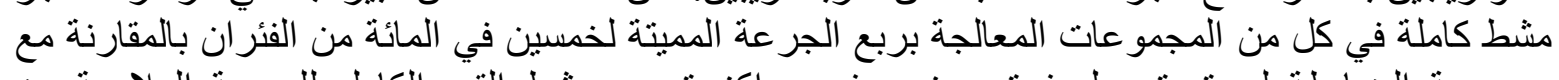

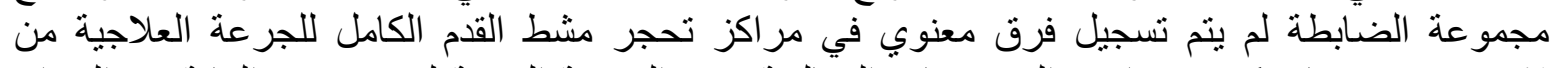

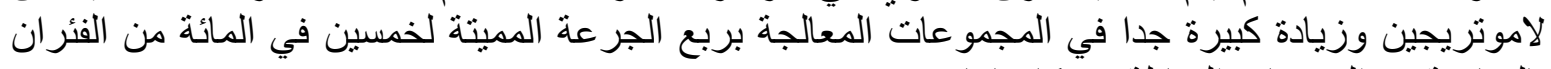

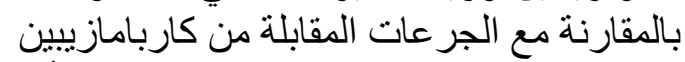

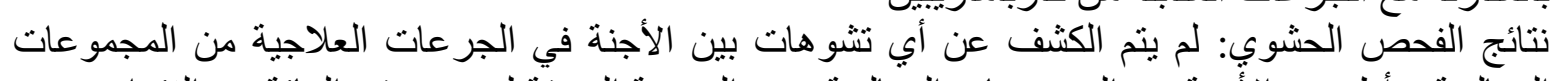

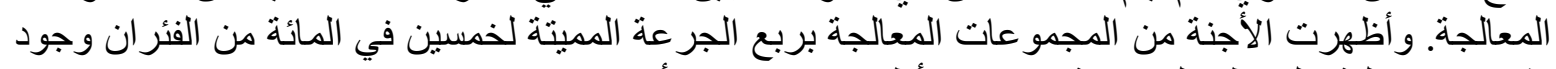

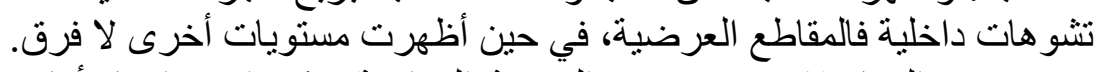

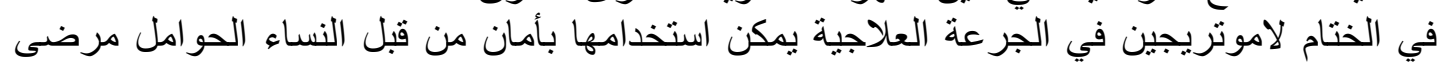

